Józef M. FISZER

Polska Akademia Nauk

fiszer@isppan.waw.pl

\title{
WADY I ZALETY CZŁONKOSTWA \\ W UNII EUROPEJSKIEJ ORAZ \\ NOWE WYZWANIA DLA POLITYKI \\ INTEGRACYJNEJ POLSKI
}

ABSTRACT Advantages and disadvantages of membership in the European Union and the new challenges for Polish integration policy

The purpose of this article is an attempt to show from the perspective of the 12 years that have passed since Polish accession to the European Union, the pros and cons of our membership in this unprecedented European project, and the analysis of the importance of this fact for the Polish domestic and foreign policy. Furthermore, the article shows the current threats the Union is facing and against this background presents new challenges and tasks for the Polish integration policy. The main thesis of the article is the observation that the Polish accession to the EU has been and is still one of the most important events in recent Polish history and success of its international policy. She became almost a turning point in Polish domestic and foreign policy. Poland thanks to the accession to the EU has strengthened its position in Europe and in the world, but today we must develop a new strategy and to establish further tasks and goals for the Polish integration policy, which should be adequate for the rapidly changing international reality.

Słowa kluczowe: Unia Europejska, Polska, negocjacje, europeizacja, współpraca, wzrost gospodarczy

Keywords: European Union, Poland, negotiations, europeanisation, cooperation, economic growth 


\section{WSTĘP}

Polska po długich negocjacjach akcesyjnych 1 maja 2004 r. stała się wreszcie członkiem Unii Europejskiej (UE). Na ten moment czekaliśmy de facto 15 lat, poczynając od 1989 r., kiedy to Polska stała się suwerennym i demokratycznym państwem oraz wyraziła wolę „powrotu do Europy”. Nasza droga do Unii Europejskiej nie była jednak ani łatwa, ani prosta, ale zakończyła się sukcesem. Był to sukces polskiej polityki zagranicznej i efekt pracy całego społeczeństwa, które po 1989 r. znalazło się w ciężkim położeniu i szansę na pozytywną zmianę upatrywało w akcesji do Unii Europejskiej. Negocjacje udało się zakończyć 13 grudnia 2002 r. w trakcie szczytu UE w Kopenhadze, ale ostateczną decyzję w sprawie członkostwa podjęli Polacy w referendum akcesyjnym w dniu 2 czerwca 2003 r. Pozytywny wynik tego referendum $(77,45 \%$ głosujących opowiedziało się za wejściem Polski do UE) pokazał, w jakim kierunku ma podążać polska polityka zagraniczna, aby zapewnić Polsce godne miejsce w Europie. Ówczesny minister spraw zagranicznych Włodzimierz Cimoszewicz w $2004 \mathrm{r}$. pisal, że polska polityka zagraniczna będzie [...] polityka dziatania zbiorowego, polityka realizowana poprzez wielkie struktury, których staliśmy sięcztonkiem - Unię Europejska i NATO2.

O ile jednak członkostwo w UE było traktowane jako fundament bezpieczeństwa gospodarczego Polski, to za gwaranta bezpieczeństwa militarnego od 1989 roku uważano Sojusz Północnoatlantycki, ze szczególnym uwzględnieniem roli Stanów Zjednoczonych. To jednak powodowało, że pozycja Polski w strukturach euroatlantyckich od początku była dość skomplikowana. Był to efekt swoistej dychotomii dotyczącej strategicznych celów polityki zagranicznej Polski. Z jednej bowiem strony dopiero co zostaliśmy członkiem NATO (12 marca 1999 r.), z wszystkimi tego faktu konsekwencjami, a już głośno dobijaliśmy się do bram UE, chcąc także partycypować w europejskim modelu bezpieczeństwa, którego przeciwnikiem były Stany Zjednoczone.

Obchodzony w 2014 r. jubileusz 10-lecia członkostwa Polski w Unii Europejskiej był też dobrą okazją do refleksji i naukowych dyskusji nad jej problemami i perspektywami, a także nad dotychczasowymi sukcesami, porażkami oraz przyszłością polskiej polityki integracyjnej i jej nowymi wyzwaniami. Taki też jest cel niniejszego opracowania, a jego główną tezą jest konstatacja, że akcesja Polski do Unii Europejskiej była i jest

Dużą rolę w reorientacji polskiej polityki zagranicznej po 1989 r. i w „powrocie Polski do Europy” odegrał rząd pierwszego od 45 lat niekomunistycznego premiera Tadeusza Mazowieckiego, bez którego nie weszlibyśmy ani do NATO, ani do Unii Europejskiej. Zob. szerzej na ten temat: A. Wielowiejski, Tadeusz Skuteczny, „Gazeta Wyborcza” 2015, 12-13 IX, s. 36-37; A. Brzeziecki, Tadeusz Mazowiecki. Biografia naszego premiera, Kraków 2015; R. Graczyk, Od uwiktania do autentyczności. Biografia polityczna Tadeusza Mazowieckiego, Warszawa 2015.

2 Zob. W. Cimoszewicz, Krajobraz za horyzontem. Polityka zagraniczna RP po wejściu do Unii Europejskiej, „Sprawy Międzynarodowe” 2004, nr 2, s. 13. Por. także: J. Kułakowski, L. Jesień, Przebieg negocjacji akcesyjnych Polski w 2001 roku, „Rocznik Polskiej Polityki Zagranicznej” (Warszawa) 2002, s. 45; T. Łoś-Nowak, Polska - cele, aspiracje, kierunki, [w:] Polityka zagraniczna. Aktorzy, potencjaty, strategie, red. taż, Warszawa 2011, s. 278. 
nadal jednym z najważniejszych wydarzeń w dziejach najnowszych Polski. Przystąpienie do UE przyniosło bowiem wiele korzyści dla naszego państwa oraz jego obywateli. Jednym z najistotniejszych benefitów płynących z akcesji była i jest nadal możliwość swobodnego przemieszczania się po większości krajów europejskich bez odczuwania fizycznych granic oraz międzynarodowych ograniczeń.

Dziś oczywiste jest, że akcesja Polski do UE stała się wręcz przełomową cezurą w powojennej historii Polski, zwłaszcza jeśli idzie o jej politykę wewnętrzną i zagraniczną. Nie ulega bowiem wątpliwości, że wejście Polski do struktur euroatlantyckich miało duże znaczenie dla jej dalszego rozwoju społeczno-gospodarczego i umocnienia pozycji na arenie międzynarodowej ${ }^{3}$.

Dziesięć, a dziś de facto już dwanaście lat członkostwa Polski w Unii Europejskiej to również dobra perspektywa, aby sporządzić bilans naszej obecności na unijnych salonach, a więc przeanalizować wynikające z tego faktu wady i zalety oraz pozytywne i negatywne doświadczenia, a także odpowiedzieć na pytania dotyczące przyszłości i nowych wyzwań stojących przed polską polityką integracyjną i przed Unią Europejską. Nie jest to jednak zadanie łatwe, bo na temat Unii Europejskiej i naszej polityki unijnej wciąż mamy rozbieżne opinie, tak wśród elit politycznych, jak i zwykłych obywateli. Jest to efekt niewiedzy i zbyt wygórowanych nadziei i oczekiwań, jakie wiązaliśmy z akcesją Polski do Unii Europejskiej, a które nie do końca się spełniły. Po 1989 r. marzyliśmy - tak jak dziś Ukraińcy i Białorusini - o szybkim powrocie do Europy. Chcieliśmy jak najszybciej znaleźć się w silnej Unii, która będzie gwarantem naszych interesów w Europie i na świecie, a dziś boimy się tej Unii, którą rzekomo rządzi niemiecko-francuski duet, dbający o zachowanie suwerenności swoich państw, zarazem zmuszają do rezygnacji z niej wszystkie inne państwa. Oskarża się Unię Europejską, że odeszta od wartości chrzésijańskich, że poszta w lewo, ku liberalizmowi, a nawet $w$ strone lewactwa. Wytyka się UE wady i wskazuje na błędy w polskiej polityce integracyjnej ${ }^{4}$.

Nota bene nie jesteśmy tutaj wyjątkiem. Wiele innych państw pod adresem Unii Europejskiej wysuwa dziś podobne oskarżenia, o czym piszę w dalszej części niniejszego artykułu. I nie są to pretensje bezpodstawne, gdyż Unia Europejska i jej wielkie projekty wspólnotowe dziś tracą urok, a zyskują pomysły ksenofobiczne, bo dobrobytu niby ciągle przybywa, ale pracy w Europie, także w Polsce, jest coraz mniej (dziś pracy u nas nie ma $8,1 \%$ obywateli) i ludzie stają się - wbrew oczekiwaniom - coraz biedniejsi. Polska należy do najszybciej rozwijających się państw, a zarazem do najszybciej starzejących się społeczeństw w Europie - dzieci rodzi się u nas coraz mniej. Co bardziej wątpiącym

Zob. J.M. Fiszer, Pozytywne i negatywne doświadczenia Polski po dziesięciu latach cztonkostwa w Unii Europejskiej, [w:] Dziesięć lat cztonkostwa Polski w Unii Europejskiej. Próba bilansu i nowe otwarcie, red. tenże, Warszawa 2015, s. 23-50. Por. także: Dziesięć lat polskich doświadczeń w Unii Europejskiej. Problemy prawnoadministracyjne, red. J. Sługocki, Wrocław 2014; Polska w procesie integracji europejskiej. Dekada doświadczeń (2004-2014), red. K.A. Wojtaszczyk, M. Mizerska-Wrotkowska, W. Jakubowski, Warszawa 2014.

4 Zob. M. Janicki, Ucieczka na Zachód, „Polityka” 2014, 26 III-1 IV, s. 12.

5 Zob. Osiem lat gospodarki pod rządami Platformy i ludowców, „Gazeta Wyborcza” 2015, 5-6 IX, s. 10. 
trudno się w tym odnaleźć, a brak wiedzy i zagubienie napędzają ruchy nacjonalistyczne $i$ antysystemowe oraz populistyczne $i$ antyunijne.

Wszystko wskazuje na to, że Unia Europejska, będąca efektem dotychczasowych procesów integracyjnych, przeżywa poważny kryzys i znalazła się na rozdrożu. Ujawniły się jej różne mankamenty, a o jej zaletach mało kto dziś mówi. Grozi jej rozpad. Teoretycy i praktycy zadają sobie pytania, dlaczego tak się stało, jakie są tego przyczyny i co dalej z Unią Europejską. Wieloletni kryzys finansowo-gospodarczy oraz konflikty międzynarodowe w bliskim i dalszym otoczeniu UE pokazują, że projekt ten źle funkcjonuje tak w aspekcie ekonomicznym, jak i społecznym, politycznym oraz kulturowym. Nieefektywne są unijne polityki, a zasady i mechanizmy ich działania budzą wiele zastrzeżeń i wymagają radykalnych zmian. UE pilnie potrzebuje zmian i nowych wizji oraz nowych rozwiązań o charakterze teoretycznym i utylitarnym ${ }^{6}$.

Zmian potrzebuje też polska polityka zagraniczna, w tym również polityka wobec UE i w Unii, która musi uwzględniać zmieniające się otoczenie międzynarodowe Polski i jej rosnący potencjał oraz pozycję w Europie i na świecie. Polska polityka zagraniczna nie może być ani zbyt europocentryczna, ani nadmiernie proamerykańska, ani proniemiecka, ani też antyrosyjska. Musi być przede wszystkim realistyczna. Powinna postrzegać współczesny świat jako system naczyń połączonych i złożoną całość. Bez zrozumienia dzisiejszych procesów globalnych, np. islamu nie jako monolitu, ale najbardziej skłóconej wewnętrznie cywilizacji, nie jest możliwe ani trafne definiowanie priorytetów polityki zagranicznej, ani tym bardziej skuteczne jej uprawianie. Dla Polski ważne powinny stać się relacje ekonomiczne Niemiec z Azją czy też taktyczny sojusz Rosji i Chin. Rzadko zastanawiamy się nad negatywnymi konsekwencjami ewentualnego wikłania się Stanów Zjednoczonych w konflikt w Azji Południowo-Wschodniej dla nas i dla całej Europy. Tymczasem świat staje się coraz bardziej niespokojny i nieprzewidywalny. Inaczej jednak niż w latach zimnej wojny głównym czynnikiem destabilizującym stały się Stany Zjednoczone, które słabną i tracą dziś swoją hegemonialną pozycję na świecie. Utrata monopolistycznej pozycji dolara, idący za tym kryzys finansowy w USA (długi Waszyngtonu przekraczają 18 bln dolarów), a także wzrost konkurencyjności gospodarczej i politycznej ChRL i pozostałych krajów z grupy BRIC popchnęły Waszyngton do prób destabilizowania wielu obszarów w sąsiedztwie głównych konkurentów. Afryka Północna, Bliski Wschód czy Ukraina to nowe obszary, na których toczą się konflikty zbrojne o niskiej intensywności, ale jeden z nich jest niebezpiecznie blisko Europy, a drugi graniczy z Polską ${ }^{7}$. To zmusza do zastanowienia się nad nową strategią dotyczącą bezpieczeństwa narodowego, w tym także polityki zagranicznej, i dalszego rozwoju gospodarczego Polski, jeśli nasz kraj ma zachować względną suwerenność oraz stać się dobrym miejscem egzystencji dla swych obywateli.

Zob. J.M. Fiszer, Unia Europejska jedenaście lat od rozszerzenia na Wschód i jej perspektywy w XXI wieku, „Myśl Ekonomiczna i Polityczna” 2015, nr 1(48), s. 113-158; J. Zielonka, Koniec Unii Europejskiej?, Warszawa 2014.

Zob. T. Hypki, Nowy wyścig zbrojeń w Europie?, „RAPORT. Wojsko. Technika. Obronność” 2015, nr 9, s. 4. 


\section{POLSKA I UNIA EUROPEJSKA PO WIELKIM ROZSZERZENIU}

Dziś mamy dwie opcje, dwa spojrzenia na UE i na efekty po 14 latach członkostwa Polski w Unii Europejskiej: pozytywne i negatywne, determinowane przynależnością partyjną (polityczną) i wyznawaną aksjologią. Z jednej strony akceptuje się tę organizację i wskazuje na jej pozytywną rolę w świecie oraz na potrzebę włączenia Polski w jej decyzyjny mainstream i podkreśla pozytywny bilans naszego członkostwa w UE. $\mathrm{Z}$ drugiej zaś strony pokazuje się niebezpieczeństwa i zagrożenia płynące z Brukseli oraz eksponuje negatywne skutki akcesji dla Polski. W związku z tym chce się pogłębiania integracji i wzmocnienia UE albo odwrotnie - postuluje się, żeby Unię politycznie i ideologicznie rozmiękczyć, rozluźnić, tak zmienić, aby przekształciła się de facto w jakieś niezobowiązujące stowarzyszenie suwerennych państw ${ }^{8}$. Jednocześnie wytyka się UE wiele wad, m.in. brak zdecydowania i solidarności, niezdolność do mówienia jednym głosem, bierność na arenie międzynarodowej, oraz zarzuca się jej partykularyzmy i inne mankamenty9. Sami też nie jesteśmy bez grzechu. Polska woli być biorcą europejskiej solidarności niż jej dawcą, co pokazuje obecny kryzys migracyjny. Podkreślamy nasze członkostwo w UE, gdy są pieniądze do wzięcia z budżetu unijnego, i je bierzemy, ale gdy wybucha kryzys migracyjny, zapominamy o tym, że Unia to też my, i nie akceptujemy jej działań na rzecz rozwiązania problemu uchodźców z Bliskiego Wschodu i Afryki. Podobnie jak premier Węgier Viktor Orbán, który mówi, że To nie jest problem europejski. To jest problem niemiecki - myśli dziś wielu polityków w Polsce, Czechach i na Słowacji ${ }^{10}$. Tymczasem w obliczu bezprecedensowej fali uchodźców potrzebne są działania nadzwyczajne całej UE i niezbędna jest nadzwyczajna solidarność. Naszym moralnym obowiązkiem jest pomóc ludziom uciekającym przed wojną i prześladowaniami, bez względu na ich rasę, narodowość czy wyznanie.

W czasie, który upłynął od akcesji Polski do UE i jej wielkiego rozszerzeniu na Wschód, ujawnity się też - wzmocnione kryzysem finansowo-gospodarczym z lat 2008-2014 oraz kryzysem migracyjnym w 2015 r. - wszystkie deficyty i nieprawidłowości tego wielkiego europejskiego projektu, jakim bez wątpienia jest Unia Europejska. Ponadto zaostrzył się kryzys systemów demokratycznych w wielu państwach należących do Unii. Wzrost siły i znaczenia prawicowego populizmu w krajach o długiej tradycji liberalnej, jak np. Holandia, Dania i Szwecja, zaskakująca eksplozja katolickiej antymodernistycznej reakcji we Francji, gwałcąca suwerenność pacyfikacja Grecji, podsycany nacjonalistycznymi nastrojami separatyzm kataloński i szkocki pokazują, że demokracja w Europie przeżywa głęboki kryzys. Jak go jednak zdefiniować, skoro wszystkie struktury polityczne i państwowe na różnych poziomach sprawowania wła-

Zob. R. Krasowski, Imperium świętego spokoju, „Polityka” 2014, 7-13 V, s. 24-26.

Zob. M. Schulz, Skrępowany olbrzym. Ostatnia szansa Europy, Warszawa 2014, s. 41.

10 Zob. W. Maziarski, PiS straszy Niemcami - że szantażują Europę uchodźcami, „Gazeta Wyborcza” 2015, 10 IX, s. 5; K. Bem, J. Makowski, Biedni Polacy patrza na uchodźców, „Gazeta Wyborcza” 2015, 10 IX, s. 7; F. Gańczyk, Trudna gościnność, „Polityka” 2015, 9-15 IX, s. 48. 
dzy w UE działają w miarę sprawnie? A z drugiej strony, dlaczego w Unii mamy tak wiele różnych przejawów gniewu i oburzenia: setki tysięcy „oburzonych” protestujących w 2011 r. i później w wielu miastach Europy, setki tysięcy francuskich katolików protestujących przeciwko małżeństwom dla wszystkich oraz ideologii gender w $2013 \mathrm{r}$. i w styczniu roku 2014; jak wytłumaczyć polską mobilizację przeciwko porozumieniu ACTA w 2012 r. czy masowy bunt Greków w latach 2014-2015 przeciwko surowym warunkom dyktowanym im przez władze Eurolandu z RFN na czele ? ${ }^{11}$ Do tego dochodzą dziś masowe protesty w większości państw Europy przeciwko unijnej polityce imigracyjnej i eksplozja niechęci wobec przyjmowania uchodźców z Bliskiego Wschodu i Afryki ${ }^{12}$.

W świetle powyższych faktów nie napawa też optymizmem orędzie o stanie UE, które szef Komisji Europejskiej Jean-Claude Juncker wygłosił 9 września 2015 r. w Parlamencie Europejskim, podkreślając m.in.:

Czas, byśmy zaczęli mówić otwarcie o poważnych problemach, przed jakimi stoi Unia Europejska. Bo jej stan nie jest dobry. Nie ma w tej Unii dość Europy. I nie ma w Unii dość Unii. Musimy to zmienić już teraz. [...] Potrzebujemy wzmocnienia europejskiej obecności w polityce zagranicznej. [...] Sytuacja ekonomiczno-spoteczna mówi sama za siebie: $w$ Unii Europejskiej jest dziś ponad 23 mln bezrobotnych, z czego ponad potowa rok i dtu$\dot{z} e j$. W samej strefie euro nie ma pracy ponad $17,5 \mathrm{mln} l u d z i . W$ uzdrowieniu sytuacji przeszkadza globalna destabilizacja. Dtug publiczny przekracza w UE średnio 88\% PKB, w strefie euro siega niemal 93\%. Kryzys nie minat, zostat tylko powstrzymany. Naznaczyt Unie gtębokimi zróżnicowaniami. Zdewastowat nasz potencjat wzrostu, naktadajac sie na dtugofalowy trend pogtębiania się nierówności. Wszystko to podsycato wątpliwości co do postępu spotecznego i korzyści z bycia razem. [...] Trzeba nam w Europie więcej Unii. [...] Musimy wreszcie dorosnać i przedtożyć wspólny interes ponad interesy narodowe ${ }^{13}$.

Już wybory do Parlamentu Europejskiego, które odbyły się w dniach 22-25 maja 2014 r., pokazały, że Europejczycy, w tym również Polacy, są niezadowoleni i zagubieni i jest im dziś dużo trudniej wyobrazić sobie, jak Unia Europejska będzie wyglądała za 10 lat. Sondaże mówią, że ponad 60\% Europejczyków obawia się, że ich dzieci będą miały gorsze życie niż oni sami ${ }^{14}$. Już dzisiaj w UE mamy niemałą rzeszę poszkodowanych, wykluczonych i obrażonych, którzy przyczyny niepowodzenia upatrują w miałkości i sprzedajności swoich elit i żądają, by przestać ulegać dyktatowi kosmopolitycznych biurokratów i finansistów. Jaskrawym tego przykładem jest dziś wspomniana Grecja i przeprowadzone tam w dniu 5 lipca 2015 r. referendum, w wyniku którego

11 Zob. E. Bendyk, Odzyskiwanie demokracji, „Res Publica Nowa” 2014, 26 V; Ł. Wójcik, Strefa bólu, „Polityka” 2015, 1-7 VII, s. 48-50.

12 Zob. M. Czarnecki, M. Rębała, Europejczycy zawieszeni między strachem a wspótczuciem, „Gazeta Wyborcza” 2015, 10 IX, s. 4-5.

13 Zob. J. C. Juncker, Raport o stanie Unii Europejskiej. Pora na uczciwość, jednosśc i solidarność, „Gazeta Wyborcza" 2015, 12-13 IX, s. 16.

14 Zob. Mniej Europy, więcej Europy. Z Iwanem Krastewem rozmawia Adam Leszczyński, „Gazeta Wyborcza” 2014, 31 V-1 VI, s. 23; J.M. Fiszer, Unia Europejska po wyborach do Parlamentu Europejskiego z 2014 roku i jej przysztość, „Myśl Ekonomiczna i Polityczna” 2015, nr 4(51), s. 145-174. 
zdecydowana większość Greków z premierem Aleksisem Tsiprasem na czele odrzuciła warunki nowej, trzeciej już transzy zagranicznej pomocy ${ }^{15}$.

Niestety również unijni przywódcy są zagubieni, wręcz bezradni. Zajmują się gospodarką w skali makro, a ludzie borykają się z problemami na poziomie codzienności. Były przewodniczący Rady Herman Van Rompuy tuż po wyborach do Parlamentu Europejskiego stwierdził, że wyborcy sformutowali silne przestanie i w związku z tym Rada musi daćjasne wytyczne na przyszłość. Wtórował mu przewodniczący Parlamentu Europejskiego Martin Schulz, ostrzegając, że polityka nie jest w stanie wyegzekwować prymatu nad wielonarodowymi koncernami, a państwa członkowskie dają się łatwo rozgrywać przeciwko sobie przez innych wielkich graczy ${ }^{16}$.

W końcu rząd i parlament Grecji przyjęły dyktat UE i Międzynarodowego Funduszu Walutowego, ale jak pisze znany politolog i publicysta Iwan Krastew:

Lewicowemu populiście Tsiprasowi nie udato się wytargować dla Grecji lepszych warunków, a prawdziwym politycznym zwycięzca najprawdopodobniej okaże się nie umiarkowane centrum, lecz antyeuropejska prawica. I podczas gdy europejscy przywódcy moga sobie pogratulować, że udato im się nie dopuścić do rozpadu Unii, cenq za to, że Grecja zostata uratowana gospodarczo, ale utracona politycznie, jest przeksztatcenie UE z projektu opartego na nadziejach $i$ aspiracjach w związek podtrzymywany jedynie wspólnymi lękami iniepewnościa ${ }^{17}$.

Brak zdecydowanych działań i konsekwencji w rozwiązywaniu problemów Unia podniosła do rangi politycznego credo. Ma - jak pokazują to wydarzenia na Ukrainie, w Grecji i obecny kryzys migracyjny - problemy z podejmowaniem decyzji i ich realizacją. W sprawach ważnych jest powolna i niezdecydowana, a w sprawach drobnych pedantyczna i natrętna. Jest bierna nawet w kwestii własnego bezpieczeństwa, co doprowadza Amerykę do pasji, a cieszy Rosję. Kryzys polityczny na Ukrainie i finansowy w Grecji pokazał to, co wiadomo już od dawna, a mianowicie że UE de facto nie ma żadnej wspólnej polityki zagranicznej i bezpieczeństwa oraz że jest mocno w tych kwestiach podzielona ${ }^{18}$. Przyznał to także obecny przewodniczący Komisji Europejskiej, który mówił:

Nie oszukujmy się. To, że przez minione miesiace nie potrafiliśmy wypracować szybkiej, klarownej odpowiedzi na grecki kryzys, ostabito nas wszystkich. Podkopato zaufanie do wspólnej waluty i reputację UE w świecie. [...] Jeśli chcemy dziatać na rzecz światowego pokoju, musimy wtaczyć do naszej polityki zagranicznej więcej Europy i więcej Unii. Dziś dotyczy to zwtaszcza Ukrainy. Pomoc Ukrainie w przetrwaniu, we wdrazaniu reform

15 Zob. T. Bielecki, Zamiast Grexitu cięcia i nowe kredyty, „Gazeta Wyborcza” 2015, 14 VII, s. 1; I. Krastew, Najpierw farsa, potem rozpacz, „Gazeta Wyborcza” 2015, 18-19 VII, s. 15.

16 Zob. M. Ostrowski, Koniec marzeń, „Polityka” 2014, 4-10 VI, s. 58-60. Zob. także: M. Schulz, Skrępowany olbrzym...

17 Zob. I. Krastew, Najpierw farsa, potem rozpacz..., s. 15.

18 Zob. K. Miszczak, The Polish Security and Defence Policy, „European Security \& Defence” 2015, nr 5 , s. 10-15; A. Ciupiński, Zaangażowanie Polski w realizację Wspólnej Polityki Bezpieczeństwa i Obrony Unii Europejskiej. Bilans pierwszej dekady cztonkostwa w UE, [w:] Dziesięć lat cztonkostwa Polski w Unii Europejskiej. Próba bilansu..., s. 123-142. 
i $w$ dalszym rozwoju to wyzwanie dla Europy. Przecież o niej wtaśnie marzyli zgromadzeni na Majdanie ludzie - o nowoczesnym kraju, o stabilnej gospodarce, o normalnym, uczciwym ustroju politycznym ${ }^{19}$.

Kryzysy w Grecji, na Ukrainie i imigracyjny pokazują również, że UE, niezależnie od wyobrażenia technokratów, nie jest organizacją, która potrafi szybko i sprawnie rozwiązywać powstające problemy w Europie i kształtować swoje otoczenie. Jest jedynie produktem końcowym sumy kompromisu woli rządów państw członkowskich, które również kierują się przede wszystkim własnym interesem narodowym, za co winić ich nie można. Prawdą jest również, że słabsze państwa są z góry skazane na dostosowanie się do warunków narzucanych przez silniejszych. RFN i Francja forsują w ramach UE własne interesy, i to przy współpracy z Federacją Rosyjską, a w opozycji do polityki międzynarodowej Stanów Zjednoczonych. Na tego typu zachowania nie powinno być przyzwolenia, bo jest to polityka destrukcyjna, która prowadzi do rozbicia jedności Unii i jej rozpadu. To sprawia, że Unia Europejska jest dziś słaba i lekceważona tak przez Stany Zjednoczone, jak i inne mocarstwa, z Chinami i Rosją na czele. Amerykanie narzekają, że Europejczycy nie chcą im pomóc w utrzymaniu pokoju na świecie. Że pod ich parasolem Europa zbudowała sobie bezpieczny raj, za który nie chce zapłacić; że nie reaguje na zagrożenia. Od lat trwają dyskusje, czy Europa wymyśliła nowy ład i przeszła na wyższy poziom, do kolejnej fazy politycznego rozwoju, czy jedynie skorzystała z półwiecza życia pod amerykańskim kloszem. Odpowiedź pozostaje nieznana, bo dziś nikt nie jest w stanie przewidzieć, jak zachowa się Unia, gdy stanie przed naprawdę wielkim zagrożeniem. Czy się wówczas rozpadnie, czy wspólnie pokona wroga? Dopiero ta reakcja ujawni istotę Unii i pokaże jej prawdziwe oblicze ${ }^{20}$.

Natomiast prawdą jest, że w okresie zimnowojennym na sytuację w Europie stabilizująco wpływała rywalizacja Stanów Zjednoczonych i Związku Radzieckiego. Oddziaływała ona korzystnie na postępy integracji europejskiej ze względu nie tylko na obawę przed zagrożeniem ze strony bloku sowieckiego, ale i na obecność na Starym Kontynencie Amerykanów, którzy zajmowali faktycznie pozycję hegemoniczną w systemie euroatlantyckim - dziś powoli ją tracą. Ten status Ameryki był ważnym czynnikiem blokującym możliwość pojawienia się destrukcyjnej rywalizacji wewnętrznej między największymi państwami Europy Zachodniej. Dla zachodnioeuropejskich struktur integracyjnych, tj. Wspólnot Europejskich i Unii Europejskiej, oraz ich państw członkowskich kształtowanie poprawnych relacji z Europą Wschodnią, a zwłaszcza ze Związkiem Radzieckim, stanowiło przez cały powojenny okres ważny element polityki zagranicznej. Świadczą o tym rozmaite inicjatywy kierowane wówczas pod adresem tzw. bloku państw socjalistycznych. Jako przykłady można przytoczyć zaangażowanie Wspólnot Europejskich w procesy odprężenia związane z pracami Konferencji Bezpieczeństwa

19 Zob. J.C. Juncker, Raport o stanie Unii Europejskiej..., s. 17.

20 Zob. M. Madej, Wptyw udziatu w Wspólnej Polityce Bezpieczeństwa i Obrony na polska politykę bezpieczeństwa, [w:] Polska w Unii Europejskiej. Bilans dekady, red. F. Tereszkiewicz, Warszawa 2013, s. 244-271. Por. także: S. Koziej, Potrzeba nowelizacji strategii bezpieczeństwa Unii Europejskiej, „Bezpieczeństwo Narodowe” 2011, nr 4(20), s. 76-84; K. Miszczak, Wspólna Polityka Zagraniczna i Bezpieczeństwa, „Sprawy Międzynarodowe” 2007, nr 4, s. 112-119. 
i Współpracy w Europie czy też politykę poszczególnych państw Europy Zachodniej, w tym zwłaszcza czołowych „lokomotyw” procesów integracyjnych: Francji i RFN. Ta pierwsza opowiadała się za ogólnoeuropejską współpracą ponad podziałami międzyblokowymi, a RFN ogłosiła własną Ostpolitik. Tak ukształtowała się kategoria określana mianem „polityki wschodniej”, prowadzonej najpierw przez Wspólnoty Europejskie, a następnie przez UE. Politykę tę można określić jako wspólne formutowanie określonych zatożeń, tworzenie rozwiazań instytucjonalnych oraz podejmowanie konkretnych przedsięwzięći dziatań, zarówno przez organy i instytucje unijne, jak i przez państwa cztonkowskie w zakresie ich szeroko rozumianych relacji z panstwami Europy Wschodniej ${ }^{21}$.

Zmiana ładu światowego w latach 1989-1991 negatywnie wpłynęła na procesy integracyjne w Europie, m.in. dlatego, że osłabło geopolityczne zagrożenie ze strony Rosji. Wzrosło zaś znaczenie unijnej polityki wschodniej, której głównym celem stało się utrzymywanie dobrych stosunków z następczynią Związku Radzieckiego, czyli Federacją Rosyjską. Natomiast w Rosji pod rządami prezydenta Borysa Jelcyna wspólpraca z zachodnioeuropejskimi strukturami integracyjnymi postrzegana była przede wszystkim jako jeden z ważnych sposobów włączenia państwa rosyjskiego w kształtujący się na nowo międzynarodowy system polityczny i gospodarczy. 24 czerwca 1994 r. zostało zawarte między UE a Federacją Rosyjską Porozumienie o partnerstwie i współpracy, które weszło w życie w 1997 r. Na jego mocy obie strony odbywały spotkania na szczycie z udziałem przewodniczących Rady UE i Komisji Europejskiej oraz prezydenta Rosji, a od 1998 r. zbierała się także Rada Współpracy UE - Rosja na szczeblu ministerialnym. Ważnym dla relacji UE i Rosji wydarzeniem był szczyt unijny w Kolonii w czerwcu 1999 r., podczas którego została sformułowana wspólna strategia UE wobec Rosji, określająca w sposób kompleksowy cele, środki i sposoby realizacji polityki UE wobec Federacji Rosyjskiej. Przyjęcie tej strategii położyło podwaliny pod ukształtowanie się, rozwijanego w dalszych latach, ważnego instrumentu polityki wschodniej UE, czyli tzw. partnerstwa strategicznego z Rosją. W odpowiedzi Rosja ogłosiła średniookresową Strategię rozwoju stosunków z UE (na lata 2000-2010), przypadającą na lata prezydentury Władimira Putina, który Unię Europejską traktował instrumentalnie i w sposób formalny, wręcz lekceważąco ${ }^{22}$. Szczególnie krytycznie odnosił się do ogłoszonej w 2003 r. przez Komisję Europejską Europejskiej Polityki Sąsiedztwa (EPS), podejrzewając UE o ekspansję na obszar Wspólnoty Niepodległych Państw ze szkodą dla interesów rosyjskich. Jak pisze Stanisław Bieleń:

Efektem tego stanowiska byto wytaczenie Rosji z EPS i skupienie sie na wdrażaniu "strategicznego partnerstwa" opartego na czterech przestrzeniach: ekonomicznej, wolności, bezpieczeństwa i sprawiedliwości; bezpieczeństwa zewnętrznego; oraz badań, oświaty $i$ kultury. Wydarzenia zwiazane $z$ "pomarańczowa rewolucja” na Ukrainie podzielity państwa unijne i doprowadzity do zahamowania realizacji polityki sasiedztwa. Jeszcze

${ }_{21}$ Zob. O. Barburska, Wptyw polskiej dyplomacji na ksztattowanie i realizacje polityki wschodniej UE, „Studia Europejskie” 2013, nr 4, s. 50-56.

22 Zob. S. Bieleń, Stosunki Unia Europejska - Rosja, [w:] Dyplomacja czy sita? Unia Europejska w stosunkach międzynarodowych, red. S. Parzymies, Warszawa 2009, s. 212-236; J.M. Fiszer, Zadania i cele polityki zagranicznej Wtadimira Putina, „Myśl Ekonomiczna i Polityczna” 2016, nr 1(52), s. 167-201. 
gorsze konsekwencje miat konflikt rosyjsko-gruziński w sierpniu 2008 r., który ukazat stabość Zachodu wobec Rosji. Jedność Unii Europejskiej okazata się fikcją, skuteczność wspólnego nacisku na Rosje - iluzją ${ }^{23}$.

Najpoważniejszym problemem w dotychczasowych stosunkach unijno-rosyjskich okazał się jednak wspomniany już kryzys ukraiński, do którego doszło na przełomie 2013 i 2014 r. Wprawdzie i w tym przypadku władze UE i większość państw członkowskich oficjalnie poparły nowe władze w Kijowie oraz potępiły Rosję za aneksję Kry$\mathrm{mu}$ i wspieranie wschodnioukraińskich separatystów, ale w istocie Unia pokazała po raz kolejny brak jedności - i to pomimo podejmowania pewnych wspólnych kroków, w rodzaju nakładania sankcji na Federację Rosyjską. W praktyce szybko okazało się bowiem, że podczas gdy grupa krajów najbardziej zainteresowanych rozwiązaniem tego kryzysu, z Polską na czele, domagała się już od dłuższego czasu ostrej reakcji na rosyjskie działania, to wiele innych państw zajęło pozycje bardzo ostrożne lub po prostu wykazało brak zainteresowania, niektóre zaś de facto poparły politykę Kremla, jak to zrobiły np. unijne kraje śródziemnomorskie (Włochy, Hiszpania, Portugalia i Grecja). Co więcej, podobną postawę przyjęło także kilka państw środkowoeuropejskich, z Węgrami, Czechami, Słowacją i Bułgarią na czele. Kryzys na Ukrainie i wojna rosyjsko-ukraińska postawiły również pod znakiem zapytania przyszłość relacji UE z państwami objętymi Partnerstwem Wschodnim - wspólnej idei Unii Europejskiej wobec regionu Europy Wschodniej, zapoczątkowanej w 2008 r. z inicjatywy Polski i Szwecji. Unia Europejska i Polska, rozpoczynając geopolityczną konkurencję z Rosją, nie zdawały sobie sprawy, z jaką reakcją z jej strony mogą się spotkać24. W tym kontekście wielce znamienna była także reakcja na propozycję Polski powołania unii energetycznej mającej ograniczyć uzależnienie UE od importu nośników energii z Rosji, która spotkała się z bardzo chłodnym przyjęciem, zwłaszcza ze strony Niemiec ${ }^{25}$.

Trzeba tutaj podkreślić, że wspomniane zagrożenie - nawet pod wpływem kryzysu ukraińskiego - wzrosło tylko w Europie Środkowej i w krajach nadbałtyckich. Natomiast nie wpłynęło mobilizująco na procesy pogłębiania integracji w UE. Co więcej, oddziaływanie Rosji w coraz większym stopniu wpływa destabilizująco na procesy integracyjne w Europie. Jest to związane z polityką Kremla, konsekwentnie dążącą do pogłębienia podziałów w UE. W tym też celu Rosja wspiera ugrupowania skrajne i eurosceptyczne w UE, które popierają rosyjską politykę zagraniczną ${ }^{26}$.

23 Tamże, s. 215-216. Zob. także: M. Słowikowski, Rosja wobec Europejskiej Polityki Sąsiedztwa Unii Europejskiej, „Rocznik Instytutu Europy Środkowo-Wschodniej” (Lublin) 2008, s. 85-101.

24 Zob. B. Piskorska, Adaptacja Unii Europejskiej i Polski do nowych uwarunkowań bezpieczeństwa w Europie Wschodniej. Kazus Ukrainy, [w:] Dziesięć lat cztonkostwa Polski w Unii Europejskiej. Próba bilansu..., s. 144.

25 Zob. O. Barburska, Relacje Unia Europejska - Federacja Rosyjska. Kryzys partnerstwa strategicznego, „Studia Europejskie” 2014, nr 4, s. 16-17.

26 Zob. A. Krzemiński, Car jest nagi, „Polityka” 2014, 10-16 XII, s. 56-58; R. Zięba, Międzynarodowe implikacje kryzysu ukraińskiego, "Stosunki Międzynarodowe - International Relations” 2014, t. 50, nr 2, s. 13-40; J.M. Fiszer, Geopolityczne aspekty polityki zagranicznej Ukrainy w latach 1991-2013, „Myśl Ekonomiczna i Polityczna” 2016, nr 4(55), s. 235-276. 
Dziś mającego poważne kłopoty prezydenta Władimira Putina bronią także niektórzy czołowi politycy Unii Europejskiej. Szczery bądź udawany lęk przed destabilizacją w Rosji stał się teraz głównym argumentem zwolenników miękkiej linii wobec Kremla i niezaostrzania albo wręcz łagodzenia unijnych sankcji gospodarczych. Czołowi politycy Francji i Niemiec przekonują, że Zachód zamiast grozić wzmocnieniem sankcji, powinien raczej zaoferować Moskwie ich szybkie złagodzenie, jeśli będzie „postęp” w sprawie pokoju na Ukrainie. Udają, że nie widzą, że Rosja Putina, podobnie jak dawniej Rosja carska i radziecka, delegitymizuje państwa ościenne. Paraliżuje ich modernizację, demoralizując i korumpując ich elity. Prowokuje wojny graniczne, by w końcu wchłonąć je jako „kraje zaprzyjaźnione” czy „bratnie narody”27.

Unia Europejska oraz Polska po ostatnich doświadczeniach powinny wreszcie zdać sobie sprawę z poważnego zagrożenia - strategicznego wyboru Rosji, która wyraźnie dąży do zmiany pozimnowojennego ładu. Wydarzenia na Ukrainie pokazują też, że UE nie ma obecnie pomysłu na prowadzenie skutecznej polityki sąsiedztwa, która jest rozbita grą interesów rosyjsko-niemiecko-francuskich.

Unii Europejskiej można dziś zarzucić jeszcze wiele innych wad, np. ociężałość biurokratyczną, strategiczne kunktatorstwo, egoizmy w rozwiązywaniu kryzysu w strefie euro. Można wskazywać na separatyzmy, z którymi Unia sobie nie radzi w Szkocji, Katalonii, Kraju Basków, na Korsyce i w południowym Tyrolu; na rzekome zagrożenia państw narodowych przez euroregiony. Można nawet ogłaszać rychły rozpad „brukselskiego monstrum”. A jednocześnie ta sama Unia ma wiele zalet i wciąż ogromną siłę przyciągania, o czym świadczy kolejka państw zabiegających o członkostwo i awans tych, które do niej weszły 14 lat temu, z Polską na czele. W 1989 r. PKB Polski był porównywalny z ukraińskim, wynosząc około 7 tys. dolarów, a dziś jest ponad trzykrotnie większy (około 22 tys. dolarów), zaś PKB Ukrainy nadal nie przekracza 7 tys. dolarów ${ }^{28}$.

Trzeba zatem nieustannie dokonywać nowych wyborów i ponosić ich konsekwencje. Widzieć nie tylko wady UE, ale także jej zalety. Choć UE wychodzi już z okresu dziecięcego, jeśli pamiętamy, że od podpisania w dniu 7 lutego 1992 r. powołującego ją do życia Traktatu z Maastricht upłynęły 24 lata, to wciąż zastanawiamy się, jakie i czyje wartości oraz interesy reprezentuje. Jednocześnie widzimy, że staje się ona istotnym ośrodkiem władzy, nie tylko na skutek redystrybucji i alokacji zasobów, ale także przez kształtowanie dyskursu i nadawanie nowych ram poszczególnym segmentom życia spotecznego ${ }^{29}$.

Żyjemy w świecie coraz bardziej się globalizującym i dynamicznie zmieniającym, niosącym nowe zagrożenia i wyzwania; w świecie coraz bardziej niepewnym i trudnym do przewidzenia. W unijnym i naszym interesie leży więc ustanawianie wspólnych

27 Zob. P. Bielecki, Kto zmięknie pierwszy - Unia Europejska czy Putin?, „Gazeta Wyborcza” 2015, 7 I, s. 3; O. Barburska, Relacje Unia Europejska - Federacja Rosyjska..., s. 9-33.

28 Zob. A. Krzemiński, Car jest nagi, s. 58; J.M. Fiszer, From Political Transformation to Europenization and Democracy in the New European Union Member States. An Attempt to Review Results, „Polish Sociological Review" 2016, nr 3(195), s. 373-388. 
zasad i norm, które umocnią UE i jej rolę na arenie międzynarodowej. Przekazaliśmy już Wspólnocie sporą część praw i powinniśmy oczekiwać solidarnego, podmiotowego i równego traktowania. Co więcej, przekazaliśmy je nie tylko organom, w których jesteśmy reprezentowani, ale też niezależnemu organowi, tj. Komisji Europejskiej. Dzisiaj ogromna większość obywateli naszego kraju ocenia to pozytywnie. Ważne jest teraz, żebyśmy zachowali swobodę decydowania o następnych krokach, zwłaszcza istotnych dla naszej racji stanu.

Z drugiej zaś strony państwa członkowskie Unii Europejskiej, w tym również Polska, nadal de facto są suwerenne i będą takie dopóty, dopóki decyzja o delegowaniu danej kompetencji wynikającej z suwerenności, jej wspólnym wykonywaniu lub pozostawieniu do realizacji wyłącznie na poziomie krajowym pozostanie w ich gestii. Co więcej, suwerenność jest niezbędnym atrybutem członka Unii Europejskiej - podmiot niesuwerenny nie jest bowiem w stanie wypełniać obowiązków wynikających z członkostwa ${ }^{30}$.

Niniejszy artykuł pokazuje, że po 26 latach od rozpoczęcia transformacji ustrojowej w Polsce i 12 latach od akcesji do Unii Europejskiej nie ulega wątpliwości, że nasze członkostwo w tym specyficznym, dobrowolnie zintegrowanym związku demokratycznych państw Europy było konieczne i nieuniknione. Jest to zarazem kolejna teza niniejszej publikacji. Było to jedyne właściwe rozwiązanie dla Polski, które wynikało z jej geopolitycznego położenia i doświadczeń historycznych. Wbrew wcześniejszym obawom nie zaszkodziło naszej suwerenności i tożsamości narodowej. Odrzucenie zaś członkostwa w Unii Europejskiej skutkowałoby redukcją naszych możliwości i szans na odgrywanie istotnej roli zarówno w polityce europejskiej, jak i światowej31.

Polskim zadaniem numer jeden jest dziś dalsze zmniejszenie, a w dalszej perspektywie likwidacja wciąż istniejącej luki cywilizacyjnej, dzielącej nasz kraj od państw wysoko rozwiniętych. Członkostwo w UE stanowi skuteczny środek do realizacji tego celu. Członkostwo Polski w UE daje nam taką szansę, którą powinniśmy wykorzystać, wspierając procesy integracyjne w Europie. Dlatego też, gdy dziś Unia przeżywa największe w swych dziejach trudności, gdy egoizmy narodowe biorą nierzadko górę nad solidarnością europejską, wady nad zaletami, w naszym żywotnym interesie leży jej dalsze poszerzanie i pogłębianie. W tym również aktywny udział w mechanizmach naprawczych strefy euro, do której w perspektywie - gdy szanse przeważą nad ryzykiem - powinniśmy wejść, gdyż tylko w ten sposób zapewnimy sobie miejsce w unijnym centrum. Niestety, na razie szanse te są niewielkie, ale to powinno nas mobilizować do ich zwiększania. Skoro maleńka Litwa mogła przystąpić z dniem 1 stycznia 2015 r. do Eurolandu, to dlaczego my nie możemy tego uczynić? Przyjęcie wspólnej waluty ostatecznie zakończyłoby proces integracji Polski z Unią Europejską i umocniło naszą pozycję w Europie i na świecie.

30 Zob. J. Czaputowicz, Suwerenność, Warszawa 2013, s. 330-387; M. Wojciechowski, Suwerenność tkwi w portfelu, „Gazeta Wyborcza” 2011, 21 XII, s. 16.

31 Zob. Polska w Unii Europejskiej. Bilans dekady, red. F. Tereszkiewicz, Warszawa 2013; J.M. Fiszer, System euroatlantycki przed i po zakończeniu zimnej wojny. Istota, cele i zadania oraz rola w budowie nowego tadu globalnego, Warszawa 2013; Skutki dziesięciu lat cztonkostwa w Unii Europejskiej dla suwerenności Polski, „Studia Polityczne” 2014, nr 4(36), s. 82-108. 


\section{PERSPEKTYWY UNII EUROPEJSKIEJ W NIEPEWNYM ŚWIECIE}

Aby zdiagnozować oraz ukazać pozytywne i negatywne doświadczenia Polski po 12 latach członkostwa w Unii Europejskiej, trzeba - moim zdaniem - najpierw odpowiedzieć na pytania, czym tak naprawdę jest dziś Unia i czym ona powinna być w przyszłości, aby mogła spełnić oczekiwania swoich członków i prowadzić skuteczną politykę wewnętrzną i zagraniczną oraz stać się gwarantem szeroko rozumianego bezpieczeństwa Europy, zwłaszcza dla Polski i jej dalszego rozwoju. Musimy pamiętać, że dziś mamy do czynienia z inną Unią niż w momencie naszej akcesji w dniu 1 maja 2004 r. Zmieniła się też sytuacja międzynarodowa w Europie i na świecie.

Unia Europejska jest organizacją międzynarodową, jednak nietypową ze względu na swoje cele i funkcje. Traktaty założycielskie UE to konstytucja bez państwa, a Unia to struktura prawodawcza bez władzy zwierzchniej. W kontekście transnarodowej integracji, z jaką mamy dziś do czynienia, pojawia się tutaj problem demokracji transnarodowej. Jest to koncepcyjne, teoretyczne wyzwanie, wynikające z nowej sytuacji, w jakiej znalazła się UE i jej państwa członkowskie po wejściu w życie w dniu 1 grudnia 2009 r. Traktatu z Lizbony, który nadał jej osobowość prawną ${ }^{32}$.

Traktat z Lizbony eksponuje fakt oparcia UE na wartościach demokratycznych i pokazuje, że Unia nie może budować swej przyszłości w oderwaniu od społeczeństw ani też bez uwzględnienia zasad demokracji. We wszystkich porządkach konstytucyjnych państw UE odnajdujemy pojęcia: wolności, sprawiedliwości, praw człowieka, a także gwarancję wolnych wyborów jako niezbędnego elementu funkcjonowania demokracji. Cechy te współtworzą aksjologię prawa unijnego. Wolne wybory legitymizujące działania władzy wewnątrz państwa wpływają również na demokratyzację struktury instytucjonalnej i samych instytucji Unii Europejskiej. Choć pojawia się określenie „deficyt demokracji", to nie upoważnia ono do stwierdzenia, że sama Unia, jej system instytucjonalny to przykład narzucania woli państwom i społeczeństwom. Również demokratyzacja Unii nie może być traktowana jedynie jako „swoisty wentyl bezpieczeństwa”. Problem demokratyzacji Unii może zatem być postrzegany przede wszystkim jako konflikt odnośnie do redystrybucji kompetencji pomiędzy instytucjonalnych aktorów $\mathrm{w}$ wieloszczeblowym zarządzaniu, w którym liberalna demokracja musi się wiązać z zapewnieniem legitymizacji władzom unijnym ${ }^{33}$.

32 Zob. J. Jaskiernia, Pozycja Parlamentu Europejskiego w systemie instytucjonalnym Unii Europejskiej po Traktacie z Lizbony, [w:] Parlament Europejski po Traktacie z Lizbony. Doświadczenia i nowe wyzwania, red. J.M. Fiszer, Warszawa 2011, s. 153-178; tenże, Traktat z Lizbony a problem legitymizacji demokratycznej Unii Europejskiej, [w:] Prawowitość czy zgodność z prawem. Legitymacja wtadzy w państwach demokratycznych, red. A. Preisner, Wrocław 2010, s. 298-304; J.J. Węc, Traktat Lizboński. Polityczne aspekty reformy ustrojowej Unii Europejskiej w latach 2007-2009, Kraków 2011.

33 Zob. R. Grzeszczak, Legitymizacja demokratyczna Unii Europejskiej (ewolucja procesu legislacyjnego i rola parlamentów narodowych), [w:] Suwerenność i ponadnarodowość a integracja europejska, red. J. Kranz, Warszawa 2006, s. 207-208; M. Grochalski, Wykorzystanie form demokracji bezpośredniej w procesach integracyjnych Unii Europejskiej, [w:] Wybrane zagadnienia polskiej i europejskiej demokracji, red. S. Wróbel, Torun 2008, s. 223; F. Schimmelfenning, The Normative Origins of Democracy in the 
Natomiast pojęcie deficytu demokracji (democratic deficit) w UE nawiązuje do faktu, że w procesach decyzyjnych Unii zarówno Parlament Europejski, jak i parlamenty narodowe, a więc ciała mające legitymację od wyborców (mandat demokratyczny), nie mają należytego wpływu. Termin ten jest jednak enigmatyczny i powstaje pytanie: co należy przez niego rozumieć i do jakich kwestii ma się on odnosić? Dotyka on bowiem tylko wybranych elementów konstrukcji integracyjnej $j^{34}$.

Unia, w odróżnieniu od klasycznej organizacji międzynarodowej, pełni w szerokim zakresie funkcje prawodawcze, będące podstawową przesłanką jej istnienia. Upodabnia się tym samym do państwa (zwłaszcza federalnego), ponieważ wykonuje władzę publiczną skutkującą aktami prawnymi stosowanymi pośrednio i adresowanymi nie tylko do państw, lecz również do osób fizycznych i prawnych. Legitymizacja źródeł władzy UE wynika z traktatów założycielskich ratyfikowanych przez wszystkie państwa członkowskie. Władza ta opiera się na powierzeniu Unii przez państwa określonych kompetencji władzy publicznej (art. 5 TUE, art. 90 Konstytucji RP) ${ }^{35}$.

Unia Europejska jest samonapędzającym się mechanizmem, którego istota polega na tym, że każdy etap jej ewolucji pociąga za sobą konieczność dalszych zmian systemowych, czyli rozszerzania jej kompetencji (pogłębianie integracji). Prowadzi to do stałych napięć wywoływanych zakresem i tempem zmian, definiowaniem narodowych interesów oraz pojmowaniem demokracji i suwerenności. Jest to przede wszystkim problem polityczny, a w mniejszym stopniu prawny. W relacjach międzynarodowych nie ma jednak i zapewne długo nie będzie światowego parlamentu, rządu czy sądów. Powstanie tego typu instytucji możliwe jest tylko za traktatową zgodą wszystkich państw, co zresztą ma miejsce, ale tylko w ograniczonym rzeczowo lub geograficznie zakresie ${ }^{36}$.

Klasyczna analiza natury Unii Europejskiej dowodzi, że jest to byt polityczny sui generis, o charakterze hybrydowym, czyli usytuowany pomiędzy konfederacją a federacją, ale w sposób nietypowy z punktu widzenia podziału kompetencji między poziomem krajowym i europejskim (ponadnarodowym). W ostatnich latach coraz częściej formułowane są postulaty dalszej federalizacji Unii Europejskiej, co pozwoliłoby na przezwyciężenie jej inercji, w tym również kryzysu gospodarczo-społecznego i politycznego, oraz wzmocnienie pozycji Europy na arenie międzynarodowej. Z drugiej strony wielu badaczy wskazuje, że formuła federalna (ustrój) nie jest adekwatna do istoty unijnej rzeczywistości, w tym dynamizacji procesów różnicowania się integracji europejskiej. Przekonują oni, że bardziej użyteczną dla Unii Europejskiej formułą będzie imperium, definiowane poprzez relacje asymetrii między centrum i peryferiami, zmienną struk-

European Union. Towards a Transformationist Theory of Democratization, „European Political Science Review" 2010, nr 2, s. 231-232.

34 Zob. R. Willa, Deficyt demokratyczny w Unii Europejskiej, „Athenaeum - Polski Przegląd Politologiczny" 2010, t. 23, s. 194-195.

35 Zob. J. Kranz, A. Wyrozumska, Powierzenie Unii Europejskiej niektórych kompetencji a Traktat fiskalny, „Państwo i Prawo” 2012, nr 7, s. 20-36.

36 Zob. J. Kranz, Deficyt demokracji w Unii Europejskiej?, „Sprawy Międzynarodowe” 2012, nr 3, s. 10-11. Por. także: tenże, Jak rozumieć suwerenność? Próba opisu, [w:] Suwerenność państwa i jej granice, red. S. Sowiński, J. Węgrzecki, Warszawa 2010, s. 15-46. 
turę przestrzenną, determinowaną ekspansją terytorialną oraz logiką dwupoziomowej tożsamości - tożsamość narodowa (krajowa) oraz tzw. misja cywilizacyjna ${ }^{37}$.

Unia Europejska po ostatnich rozszerzeniach straciła zapał i nie wypracowała porywającej wizji, szamocze się w politycznej doraźności, próbując z coraz większym trudem równoważyć narodowe egoizmy. Liczne kryzysy - właściwie w każdej z tzw. unijnych polityk - energetycznej, imigracyjnej, fiskalnej, klimatycznej, obronnej itp., skłaniają rządy raczej do sięgania po narzędzia własne, narodowe niż wspólnotowe. Szczególnie bolesny okazał się kryzys gospodarczy i zadłużeniowy, głównie w strefie euro, będący pokłosiem globalnego kryzysu zapoczątkowanego w Stanach Zjednoczonych w 2008 r. Jego następstwem jest dramatyczne pogorszenie sytuacji bytowej milionów Europejczyków, głównie w najbardziej dotkniętych krajach Południa (Hiszpania, Portugalia, Grecja), w rezultacie wzrostu bezrobocia i wskaźników wykluczenia społecznego. W Grecji np. bezrobocie dotyka co czwartego obywatela zdolnego do pracy i co drugiego przed 30 rokiem życia, a 70\% kredytów mieszkaniowych nie jest tam spłacanych ${ }^{38}$.

Nastąpiło dalsze rozwarstwienie wewnątrz Wspólnoty. Powoli przestaje się już tylko mówić o starej i nowej Europie, a dominujący staje się podział na dobrze radzącą sobie gospodarczo Północ i zadłużone Południe. Kryzys walutowy w strefie euro podmył fundamenty całej Unii Europejskiej. Pociągnął za sobą kryzys polityczny i symboliczny - kryzys legitymizacji władzy w UE, oraz zachwiał jej konstrukcją. Obnażył niemożność utrzymania unii gospodarczej i walutowej w jej szczątkowej formie oraz unaocznif konieczność wzmocnienia koordynacji polityk gospodarczych państw członkowskich oraz zacieśnienia integracji w kierunku unii bankowej i fiskalnej, a co za tym idzie unii politycznej. Zarazem potwierdzit, że nie można sterować wspólną walutą na podstawie samych reguł i statystyk. Nowa polityka gospodarcza, fiskalna i socjalna wymaga nieustannej politycznej oceny sytuacji.

W UE wzrasta heterogeniczność, ale też na skutek kryzysu w strefie euro rosną presje na dalszy transfer kompetencji na poziom unijny, stąd też dalsze pogłębienie zróżnicowania wydaje się nieuniknione. Jednocześnie rośnie upolitycznienie integracji europejskiej i przestaje ona być procesem przede wszystkim biurokratycznym. Każdy nowy krok na drodze do integracji generuje znaczące koszty polityczne dla poszczególnych państw członkowskich, co w konsekwencji oznacza nasilenie trendu do dalszego różnicowania integracji i tworzenie owego systemu hybrydowego, co jednak nie powinno wykluczać dyskusji o perspektywie federacyjnej ${ }^{39}$.

Zob. U. Beck, Europa kosmopolityczna: spoteczeństwo i polityka w drugiej nowoczesności, Warszawa 2009; M. Gravier, Empire vs. Federation. Which Path for Europe?, „Journal of Political Power” 2011, nr 7; A. Wierzchowska, Wptyw modernizacji i kryzysu na dynamikę zmiany w Unii Europejskiej, Warszawa 2016.

38 Zob. Ł. Wójcik, Strefa bólu, „Polityka” 2015, 1-7 VII, s. 49; Kryzysy w procesie integracji europejskiej i sposoby ich przezwycieżania, red. K.A. Wojtaszczyk, J. Nadolska, Warszawa 2015.

39 Zob. D. Leuuffen, B. Rittberger, F. Schimmelfennig, Differentiated Integration. Explaining Variation in the European Union, Basingstoke 2013; A.F. Tatham, Enlargement of the European Union, London 2009. 
Tymczasem w Brukseli trudno znaleźć polityka, który by głośno powiedział, że strefa euro w obecnym kształcie jest nie do obronienia i w związku z tym trzeba zmienić obowiązujące traktaty. Największe państwa członkowskie podważają już nie tylko gospodarcze, ale także polityczne i społeczne filary zjednoczonej Europy. Co więcej, większość Europejczyków ma wciąż niewielką wiedzę o Unii Europejskiej i nie angażuje się w sprawy europejskie. Europejczycy nie utożsamiają się z UE, a Unia jest oderwana od obywateli. Widać to wyraźnie podczas kolejnych kampanii wyborczych do Parlamentu Europejskiego, także tej ostatniej w maju 2014 r., podczas których dominują raczej sprawy krajowe. W rezultacie obywatele czują się niedoinformowanymi i przyjmują krytyczne postawy wobec decyzji Unii Europejskiej. Często też niezrozumienie Unii bierze się z politycznego rozgrywania spraw europejskich w polityce wewnętrznej. Politycy w Polsce i w innych krajach, unikając trudnych problemów wewnętrznych i chcąc zyskać poparcie wyborców, publicznie obwiniają Unię i krytykują jej instytucje. Sprzyja to narastaniu eurosceptycyzmu i tendencji renacjonalizacyjnych, co wykorzystują partie populistyczne i skrajnie nacjonalistyczne do walki o władzę. Do Europy wraca dziś nacjonalizm, a nacjonaliści wygrywają wybory do europarlamentu we Francji, Wielkiej Brytanii, Danii, Austrii, Grecji czy na Węgrzech. Hasłem francuskiego Frontu Narodowego jest $z$ dobyć Francje, zniszczyć Europe $e^{40}$.

Kryzys finansowo-gospodarczy i kryzysy w Grecji i na Ukrainie oraz imigracyjny pokazują wyraźnie, że ustrój Wspólnoty nie zdaje już egzaminu. Wyłaniają się nowe linie podziału, a największe państwa Unii Europejskiej, w tym Francja i Niemcy, tandem, który do tej pory stanowił jej lokomotywę, są przeciwne jej dalszemu poszerzaniu i pogłębianiu. Marine Le Pen, szefowa Frontu Narodowego we Francji, który cieszy się coraz większym poparciem społecznym, nie kryje, że dąży do upadku UE, określając ją jako sowiecką Unię Europejską, która ukradta suwerenność i ogranicza możliwości samostanowienia przez wtadze narodowe ${ }^{41}$.

Napięcia geopolityczne między Paryżem i Berlinem oraz między Waszyngtonem i Berlinem doprowadziły do turbulencji w procesach integracyjnych Europy i sprzyjają narastaniu nastrojów eurosceptycznych w UE. Pokazują to sondaże opinii społecznej przeprowadzane przez Komisję Europejską. Od początku kryzysu w 2008 r. systematycznie spada zaufanie do władz publicznych, zarówno tych europejskich, jak i narodowych; jednak silniej - do instytucji unijnych (spadek o blisko 30\% między rokiem 2007 a 2012; w tym samym okresie spadek zaufania do władz narodowych wyniósł średnio około $20 \%)^{42}$.

Dziś w Unii Europejskiej mamy coraz mniej solidarności, spójności i wiary co do jej perspektyw. Wrogami Unii są nie tylko eurosceptycy, ale także realiści, którzy bez trudu znajdują argumenty, że to wszystko źle działa, a więc trzeba dbać tylko o własne interesy. Tymczasem pogrążona w kryzysach, zmęczona i będąca na rozdrożu Unia

40 Zob. A. Krzemiński, Gule i bóle, „Polityka” 2014, 16-22 VII, s. 53.

41 Zob. T.G. Grosse, W oczekiwaniu na rewolucje, „Rzeczpospolita” 2014, 22 VII, s. A11.

42 Tamże. Zob. także: J. Greiner, Rechtspopulismus als sozialdemokratische Herausforderung - Das Beispiel Skandinavien, „Neue Gesellschaft-Frankfurter Hefte” 2015, nr 7/8, s. 23-26. 
Europejska potrzebuje dzisiaj odświeżenia zapomnianych słów, pojęć i emocji, które w przeszłości motywowały do wysiłków na rzecz budowy zjednoczonej, demokratycznej i bogatej Europy. Potrzebuje nowych odpowiedzialnych polityków oraz wizji i wizjonerów na miarę Jeana Moneta, Helmuta Schmidta czy Jacques’a Delorsa ${ }^{43}$. Trzeba wrócić do koncepcji Oscara Lafontaine’a, jednego z ojców euro, który w 1999 r., gdy wprowadzano wspólną walutę, mówił: Wizja zjednoczonej Europy zostanie teraz zrealizowana dzięki zrównaniu poziomów życia, pogtębieniu demokracji i triumfowi prawdziwie europejskiej kultury ${ }^{44}$.

Najwyższa pora, aby w Unii Europejskiej rozpocząć poważną debatę o wartościach podstawowych. O tym, czym jest dziś faktycznie i czym powinna być europejska tożsamość, odpowiedzialność i solidarność. Jakie obowiązki nakłada ona na bogatych, a jakie na uboższych członków unijnej rodziny. Bez wiarygodnego nazwania, przypomnienia bądź odkrycia na nowo owej europejskiej tożsamości Unia nie będzie mogła normalnie funkcjonować, rozwiązywać skutecznie swych gospodarczych, społecznych i politycznych problemów, powiększać się i rozwijać oraz modernizować, a w rezultacie dojdzie do jej jeszcze większego paraliżu, a być może nawet rozpadu lub stanie się ona co najwyżej strefą wolnego handlu.

Nie ulega wątpliwości, że po 60 latach od powstania pierwszych Wspólnot Unia Europejska potrzebuje nowej strategii rozwoju oraz daleko idącej modernizacji i demokratyzacji. Dziś musimy odpowiedzieć sobie nie tylko na pytanie, czy model demokracji w państwie może być wzorem dla Unii Europejskiej oraz czy Unia powinna stać się państwem (mocarstwem), ale przede wszystkim: co należy uczynić, aby Unia się nie rozpadta ${ }^{45}$.

Należy uczynić wszystko, aby UE była aktywnym podmiotem na arenie międzynarodowej i odgrywała istotną rolę w budowie nowego ładu międzynarodowego, którego powinna być jednym z głównych filarów. W tym celu niezbędna jest jedność i współpraca wszystkich państw należących do Unii Europejskiej, a zwłaszcza RFN i Francji. Niezbędna też jest współpraca UE i Stanów Zjednoczonych oraz UE i NATO. W związku z tym UE potrzebuje też nowej strategii bezpieczeństwa, gdyż nadal obowiązująca Europejska strategia bezpieczeństwa (z podtytułem Bezpieczna Europa w lepszym świecie), przyjęta przez Radę Europejską w grudniu 2003 r., jest dokumentem nieadekwatnym do obecnej sytuacji na świecie. Niewykorzystaną szansą na rozpoczęcie prac nad nową unijną strategią bezpieczeństwa było posiedzenie Rady Europejskiej z grudnia 2013 r. Po raz pierwszy od lat na tym szczeblu państwa członkowskie podjęły dyskusję o przyszłości CSDP. Jakkolwiek konkluzje tego spotkania nie zawierały wezwania do opracowania nowej strategii, to wskazywały na jej trzy przyszłe składniki: wspólna polityka

43 W. Malendowski, Suwerenność państw w procesie integracji europejskiej, „Przegląd Politologiczny” 2010, nr 4, s. 7-20; W. Smoczyński, Europa się chwieje, „Polityka” 2011, 29 VI-5 VII; J. Baczyński, Czy porwiemy Europę?, „Polityka” 2011, 6-12 VII.

44 Cyt. za: E. Wójcik, Strefa bólu, s. 50.

45 Zob. J.M. Fiszer, Czy państwo demokratyczne może być wzorem dla przysztej Unii Europejskiej?, „Myśl Ekonomiczna i Polityczna” 2014, nr 1(44), s. 101-125; Integracja europejska. Gtówne obszary badawcze, red. K.A. Wojtaszczyk, J. Tymanowski, P. Stawarz, Warszawa 2015. 
bezpieczeństwa, wsparta narodowymi zasobami obronnymi oraz niezbędnym zapleczem przemysłowym - konkurencyjnym na świecie i tworzącym przesłanki wzrostu gospodarczego w Europie ${ }^{46}$.

Wobec bankructwa dotychczasowej polityki wschodniej Unii trzeba też wypracować nowy kształt polityki UE wobec Rosji oraz przyjąć nową, dalekowzroczną strategię wobec tego $\mathrm{kraju}^{47}$. Jest to sprawa pilna, gdyż Rosja kwestionuje dziś ustalone wcześniej pokojowe normy, zasady i reguły obowiązujące w stosunkach międzynarodowych, spisane m.in. w takich dokumentach, jak Karta NZ, Akt końcowy Konferencji Bezpieczeństwa i Współpracy z 1975 r., Paryska Karta dla Nowej Europy z 1990 r. oraz dwa trójstronne porozumienia Rosji i Stanów Zjednoczonych z Ukrainą podpisane 15 stycznia 1994 r. w Moskwie i 5 grudnia 1994 r. w Budapeszcie. Szczególnie niebezpieczne dla pokoju w Europie staje się kwestionowanie przez Rosję zasady integralności terytorialnej państw i nienaruszalności ich granic. Podważenie tych zasad wynika z przyjętego założenia, jakoby stary porządek już nie obowiązywał, a nowy jeszcze nie został uzgodniony. Konflikt w sierpniu 2008 r. w Gruzji oraz zapoczątkowane na przełomie lutego i marca 2014 r. wypadki wokół Ukrainy i na Ukrainie potwierdzają tezę, że Rosja nie pogodziła się z nową rzeczywistością polityczno-prawną, której istotnym elementem był rozpad ZSRR i ukształtowanie się na jego obszarze 15 niepodległych państw $^{48}$. Trafnie zauważa Adam Daniel Rotfeld, że:

Obrana przez Rosje strategia polityczna prowadzi do utrzymywania stanów tymczasowości, niepewności i napięcia w formie „zamrożonych” i nierozwiązywanych konfliktów (Górski Karabach, Naddniestrze) oraz instrumentalnego traktowania rosyjskiej mniejszości w panstwach proradzieckich, wykorzystywanej jako pretekst do ingerencji wich sprawy wewnętrzne i ponownego podporządkowania. Taka filozofia polityczna stata się nowym źródtem destabilizacji i podważania trwatości pozimnowojennego porządku międzynarodowego ${ }^{49}$.

Walka o przyszłość Ukrainy zdestabilizowała środowisko międzynarodowe w bezpośrednim sąsiedztwie unijnych granic, a część państw po raz pierwszy od zakończenia zimnej wojny dostrzegła groźbę rosyjskiej agresji. Jest to dziś sytuacja niepokojąca dla Europejczyków, którzy obdarzeni kilkoma dekadami pokoju wykluczyli już możliwość konfliktu zbrojnego na naszym kontynencie. Dziś powinno nastąpić na nowo zdefiniowanie roli UE w polityce obronnej oraz w relacjach z NATO i Stanami Zjednoczonymi. Należy jak najszybciej przyjąć wspólną strategię, aby zabezpieczyć

46 Zob. Rada Europejska 19-20 grudnia 2013 r. Konkluzje, [online] http://www.consilium.europa.eu. Zob. także: R. Kupiecki, Unia Europejska i problemy strategii bezpieczeństwa podmiotów zbiorowych, „Sprawy Międzynarodowe” 2014, nr 4, s. 88.

47 Zob. A. Krzemiński, Niemcy na huśtawce, „Polityka” 2014, 30 VII-5 VIII, s. 43-45; J.M. Fiszer, Wspólnota euroatlantycka $i$ jej perspektywy $w$ nowym systemie międzynarodowym, cz. 2, „Studia Polityczne” 2015, nr 2, s. 183-205; G. Erler, Mit einer neuen Ostpolitik aus der Krise?, „Neue Gesellschaft-Frankfurter Hefte" 2015, nr 7/8, s. 37-40.

48 Zob. A.D. Rotfeld, Porzadek międzynarodowy. Parametry zmiany, „Sprawy Międzynarodowe” 2014, nr 4. s. 31-32. 
Europę i świat przed imperialnymi zakusami prezydenta Rosji, który chce przywrócić swemu krajowi pozycję globalnego mocarstwa oraz odzyskać wpływy na terenach postsowieckich, tworząc w tym celu Unię Euroazjatycką, która zainaugurowała swoją działalność 1 stycznia 2015 r. i ma na celu równoważyć wpływy UE w Europie i na świecie ${ }^{50}$.

Z drugiej strony, biorąc pod uwagę fakt, że we współczesnym świecie, w którym decydują twardo definiowane interesy państw, zwłaszcza mocarstw, trzeba się z nimi liczyć. Tym bardziej, jak pokazuje to niniejsza analiza, dziś nadal dużą przydatność eksplanacyjną w badaniu rzeczywistości międzynarodowej zachowuje paradygmat realistyczny, który dowodzi, że świat współczesny szybko się zmienia i na naszych oczach powstaje nowy ład międzynarodowy, w którym główną rolę zaczynają odgrywać tzw. mocarstwa wschodzące, zaliczane do grupy BRIC. Twórcy nowego ładu globalnego muszą też brać pod uwagę fakt, że liberalna demokracja oraz jej wartości i zasady dziś są uznawane jedynie przez część wysoko rozwiniętych państw, a w szczególności przez transatlantycką wspólnotę. W związku z tym, jak pisze Ryszard Zięba:

Jest więc kwestia strategicznego wyboru, przed jakim stoi Zachód. Czy samodzielnie, a do tego spychając Rosje na pozycje podrzędna, jest w stanie sprostać wyzwaniom bieżacym, jakie stwarza konflikt bliskowschodni i przybierajacy na sile fundamentalizm islamski, a przede wszystkim czy zdota podjać dtugofalowe wyzwanie, jakie niesie wzrost znaczenia Chin czy Indii. Paradoksalnie kryzys ukrainski powinien uświadomić wszystkim zaangażowanym podmiotom zewnętrznym, że porozumienie się Zachodu z Rosja w sprawie Ukrainy może mieć przetomowe pozytywne znaczenie dla catego globalnego tadu międzynarodowego 51 .

Na razie Rosja wybrała inną strategię, a mianowicie budowanie konsolidacji własnego społeczeństwa na lansowaniu tezy o zagrożeniu zewnętrznym, płynącym z Zachodu. W rzeczywistości zachodnie granice Rosji nigdy nie były równie bezpieczne, jak są teraz. Natomiast poważne zagrożenia rodzą się na jej południowych rubieżach oraz na południu Tadżykistanu, którego granic broni rosyjska armia. Uzasadnia to rozważenie na nowo potrzeby współpracy w zakresie bezpieczeństwa między Rosją a Zachodem, a zwłaszcza między Rosją a UE i NATO na podstawie katalogu wspólnych zagrożeń sporządzonego w Lizbonie na posiedzeniu Rady NATO-Rosja w listopadzie 2010 r. Dokument ten nie stracił na aktualności. Jednak współpraca ta nie może się opierać na werbalnych zapewnieniach i deklaracjach. Wymaga respektowania w praktyce przyjętych zasad, norm i regulacji przez wszystkie zainteresowane podmioty oraz wypracowania nowych regut w tych sprawach i obszarach, gdzie to jest konieczne.

50 Zob. A. Nowak, Putin. Źródta imperialnej agresji, Warszawa 2014; Ł. Wójcik, Więzień Kremla, „Polityka” 2015, 1-6 I, s. 22-24.

51 Zob. R. Zięba, Międzynarodowe implikacje kryzysu ukraińskiego, „Stosunki Międzynarodowe - International Relations" 2014, t. 50, nr 2, s. 39-40. Zob. także: R. Kuźniar, Europa i porządek międzynarodowy, „Stosunki Międzynarodowe - International Relations” 2014, t. 50, nr 2, s. 41-56; Unia Europejska jako aktor na scenie globalnej. Razem czy osobno?, red. B. Góralczyk, Warszawa 2014. 


\section{EFEKTY CZŁONKOSTWA W UNII EUROPEJSKIEJ I NOWE WYZWANIA DLA POLSKIEJ POLITYKI INTEGRACYJNEJ}

Z perspektywy 12 lat nie ulega wątpliwości, że członkostwo Polski w Unii Europejskiej ma więcej zalet niż wad. Dobrze służyło i nadal służy polskiej racji stanu. Wpływa bowiem pozytywnie na potencjał gospodarczy Polski, wewnętrzną stabilizację polityczną i na korzystne relacje z sąsiadami oraz umacnia nasz prestiż pośród innych państw i narodów. Oczywiście pozycja państwa w stosunkach międzynarodowych jest wypadkową wielu rozmaitych wyznaczników o charakterze obiektywnym i subiektywnym, a zwłaszcza gospodarczych, politycznych, wojskowych, finansowych, surowcowych, naukowo-technicznych i kulturowych ${ }^{52}$. Wpływa na nią także otoczenie państwa i jego sojusze oraz relacje z innymi państwami, a zwłaszcza z sąsiadami ${ }^{53}$.

Po akcesji do UE Polska przestała być postrzegana jako słaby, postkomunistyczny kraj, który jest „petentem” koncentrującym się na dołączeniu do struktur euroatlantyckich. Stała się aktywnym uczestnikiem systemu euroatlantyckiego, który gwarantuje jej suwerenność i bezpieczeństwo ${ }^{54}$. Przed Polską otwarły się nowe możliwości współpracy gospodarczej i politycznej oraz uczestniczenia w różnych unijnych politykach i programach służących ochronie dóbr kultury, a tym samym umacnianiu naszej tożsamości kulturowej i suwerenności narodowej, których utratą straszono Polaków przed akcesją ${ }^{55}$.

Po 12 latach członkostwa w Unii Europejskiej możemy stwierdzić, że summa summarum dla Polski bilans jest dodatni, a zyski z tego tytułu są bezdyskusyjne. Zdobyliśmy olbrzymie doświadczenia we wszystkich dziedzinach życia, które będą procentowały w bliższej i dalszej perspektywie czasu. Polki i Polacy są zadowoleni z członkostwa w Unii Europejskiej - tak przynajmniej wynika z badań opublikowanych przez CBOS wiosną 2014 r. 63\% respondentów uważa, że obecność w Unii przynosi naszemu państwu więcej korzyści niż strat, podczas gdy jedynie 13\% przynależność do UE ocenia negatywnie. Badania pokazują jednak wyraźnie, że ankietowani lepiej oceniają skutki integracji dla Polski w ogóle niż dla siebie osobiście. Choć większość z nas generalnie

52 Zob. K. Łastawski, Polska racja stanu po wstapieniu do Unii Europejskiej, Warszawa 2009, s. 171-204; Polska w stosunkach międzynarodowych, red. S. Bieleń, Warszawa 2007.

53 Szerzej na temat pozycji (miejsca) i roli państwa na arenie międzynarodowej i ich determinantach zob. J. Zając, Role międzynarodowe państwa średniego, „Krakowskie Studia Międzynarodowe” 2013, nr 4, s. 16-17; M. Bielecka, Role międzynarodowe państwa, [w:] Wstęp do teorii polityki zagranicznej, red. R. Zięba, Toruń 2007, s. 181.

54 Zob. System euroatlantycki i bezpieczeństwo międzynarodowe w multipolarnym świecie. Miejsce i rola Polski w euroatlantyckim systemie bezpieczeństwa, red. J.M. Fiszer, Warszawa 2013; A. Orzelska-Stączek, Rola Polski w euroatlantyckim systemie bezpieczeństwa w ocenie gtównych sit politycznych, [w:] System euroatlantycki i bezpieczeństwo międzynarodowe w multipolarnym świecie..., s. 281-300.

55 Zob. J.M. Fiszer, Unia Europejska a Polska - dziś i jutro, Torun 2002; G. Dziamski, Rola kultury w procesie integracji europejskiej, „Europa Wschodu i Zachodu” 1999, nr 3, s. 112-128; J.M. Fiszer, Korzyści i zagrożenia oraz koszty przystąienia Polski do Unii Europejskiej, „Przegląd Europejski” 2001, nr 1, s. 37-46. 
pozytywnie odnosi się do zmian, jakie zaszły pod wpływem UE w Polsce, inaczej wygląda ocena minionych lat z perspektywy indywidualnej: zaledwie 43\% Polek i Polaków uważa, że dla nich osobiście przynależność Polski do UE jest korzystna ${ }^{56}$.

Doświadczenia uczą jednak, że nie należy upajać się samym członkostwem w gremiach najbogatszych i najpotężniejszych państw świata, do których należy także Unia Europejska, ale trzeba zapewnić Polsce jeszcze lepszą pozycję do dalszego rozwoju gospodarczego i sukcesów na arenie międzynarodowej, wykorzystując to, co już udało się nam osiągnąć po 12 latach członkostwa w Unii Europejskiej. W tym też celu, w oparciu o pozytywne i negatywne doświadczenia, należy wypracować nową, narodową, a więc ponadpartyjną strategię dla polskiej polityki zagranicznej, w tym unijnej i globalnej. Należy odbudować konsensus w polityce zagranicznej Polski. Trzeba także odpowiedzieć na pytania, czego od członkostwa w UE oczekujemy oraz co to tak naprawdę znaczy dla Polski i jej przyszłości, tym bardziej że nie wszystkie procesy gospodarcze, polityczne i społeczne przebiegają tak, jakbyśmy sobie tego życzyli. Oprócz sukcesów i profitów istnieją także porażki i trudności. Nadal należymy do państw UE o najwyższym wskaźniku bezrobocia. Wciąż spora grupa Polaków, zwłaszcza młodych, każdego roku opuszcza kraj w poszukiwaniu pracy i godziwych warunków egzystencji. 1,5 mln Polaków po 2004 r. znalazło pracę poza krajem. Nie tylko zmniejszyli bezrobocie (do $11 \%)$, ale też wspomagają gospodarkę transferami finansowymi. Ale to nie sukces, to porażka, bo okazuje się, że dla tak wielkiej liczby młodych, przedsiębiorczych i dobrze wykształconych ludzi nie mamy w kraju żadnego atrakcyjnego zajęcia. Potęguje to kryzys demograficzny, który w Polsce narasta od lat, a którego skutki gospodarcze i społeczne w przyszłości będą bardzo dotkliwe.

W roku jubileuszowym stawialiśmy sobie pytania i dziś także pytamy, czy gdyby Polska była poza strukturami Unii Europejskiej, to sytuacja w kraju byłaby lepsza. Czy istniała lub istnieje dziś inna, lepsza droga rozwoju dla Polski? Nawet jeśli nadal istnieją pewne środowiska, które udzielą odpowiedzi twierdzącej, to nie sądzę, aby mogły one poprzeć swoją odpowiedź rzetelnymi argumentami. Dla Polski w jednoczącej się Europie pod egidą Unii Europejskiej i w ogóle dla Unii nie ma alternatywy. Pokazują to pozytywne i negatywne doświadczenia po 12 latach naszego członkostwa w Unii Europejskiej.

Ponad dekada w Unii Europejskiej - ogólnie rzecz biorąc - to nie stracony czas dla Polski. Zarówno politycy, jak i eksperci czy badacze podkreślają, że Polska w ciągu ostatnich lat notuje jeden z najwyższych wzrostów gospodarczych w swojej historii. Okrzepła nasza demokracja i umocniła się gospodarka rynkowa. Mocno przyspieszył wzrost gospodarczy, a w ciągu minionych lat nasze firmy zwiększyły produkcję o połowę. Również - wbrew wcześniejszym obawom - rolnicy wyszli na swoje. W ostatniej dekadzie na polską wieś trafiło około 120 mld zł. Gospodarstwa rolne uległy powiększeniu, a dochody rolników wzrosły ponad dwukrotnie. Pięciokrotnie zwiększył się eksport towarów rolno-spożywczych (w 2013 r. był wart 20 mld euro). Mimo to rol-

56 Zob. Komunikat CBOS - Polacy oceniaja 10 lat w Unii Europejskiej, [online] http://wiadomości. dziennik.pl/wybory/artykuły/457183.cbos-polacy-oceniają-10-lat-w-unii.html. 
nicy zarabiają wciąż mniej niż statystyczny Polak - dochód na wsi to dziś $85 \%$ średniej krajowej (10 lat temu - 71\%). Wieś modernizuje się i staje się coraz mniej rolnicza tylko jedna trzecia mieszkańców żyje z rolnictwa. Spada też udział rolnictwa w PKB z 5,1\% w 2004 r. do 3,8\% w 2013 r. ${ }^{57}$

Siłą napędową PKB był przede wszystkim szybko rozwijający się eksport oraz duży napływ zagranicznych inwestycji i środków unijnych. Rozwój nie był jednak równomierny - najbardziej skorzystały bogatsze województwa, już wcześniej powiązane gospodarczo z Zachodem. W efekcie, chociaż Polacy wzbogacili się w całym kraju, to nierówności w dochodach jeszcze wzrosły. Poprawił się średni (statystyczny) poziom życia mieszkańców, m.in. dzięki napływowi inwestycji zagranicznych oraz środków finansowych z budżetu UE na sumę prawie 180 mld euro. Według danych resortu rozwoju regionalnego do 2013 r. tylko w ramach polityki spójności wpłynęły do Polski ponad 82 mld euro, czyli około 342 mld zł. Dzięki tym środkom zrealizowano prawie 172 tys. projektów ${ }^{58}$. Do 2020 r. mamy otrzymać kolejne 80 mld euro - to tak, jakby nam dodano jeden pełny roczny budżet RP. Umożliwi to dalszą, szeroko rozumianą modernizację kraju i jego rozwój. Tak więc środki unijne, które stymulowały polską gospodarkę w minionej dekadzie, wydaliśmy szybko i skutecznie, ale czy dobrze? I czy jesteśmy tak sprawni, aby dobrze wykorzystać te, które UE przyznała nam na lata 2014-2020? Odpowiadając na tak postawione pytania, ówczesny premier, a od 1 grudnia 2014 r. przewodniczący Rady Europejskiej Donald Tusk podkreślił, że:

To jest pytanie kluczowe, ale ono dotyczy dwóch różnych okresów. To, co robiliśmy do tej pory, byto może nie idealnym, ale optymalnym modelem wydawania środków. To znaczy inwestowanie przede wszystkim w twarda infrastrukture, ale nie tylko, mamy dziś bodaj najnowocześniejszy park naukowy w Europie. Jako przyktad przesadnych wydatków podaje się często Operę w Biatymstoku. Tylko dlaczego miatoby jej tam nie być, skoro tak dobrze sobie radzi i jest potrzebna? Może to nie będzie przynosito ogromnych dochodów, ale pokażcie mi takie miejsce na świecie związane z kultura wyższa, które przynosza wielkie dochody. Druga unijna siedmiolatka jest nakierowana w stronę ludzi i kwestii spotecznych. Podjęlismy tu pewne ryzyko z nadzieją, że w ten sposób domkniemy pierwszy, „murowany” etap, wykorzystamy budowana infrastrukture ${ }^{59}$.

Warto więc uświadomić sobie, że trwająca dziś debata nad przyszłością Unii Europejskiej i jej miejscem w nowym ładzie międzynarodowym to jednocześnie debata nad kierunkiem rozwoju Polski, jej suwerennością oraz miejscem na kontynencie europejskim i w systemie międzynarodowym. Dlatego też Polska musi uczynić wszystko, co w jej mocy, aby Unia była efektywnym podmiotem stosunków międzynarodowych, a jej głos był z uwagą słuchany przez pozostałych aktorów na scenie międzynarodowej.

Zob. Rolnicy wyszli na swoje, [w:] 10 lat w Unii, dodatek specjalny „Polityki” 2014, 28 IV-5 V, s. 70; A. Janowicz, Ocena wptywu środków Unii Europejskiej na wybrane wskaźniki spoteczno-gospodarcze Polski w latach 2004-2013, „Myśl Ekonomiczna i Polityczna” 2016, nr 1(52), s. 56-115.

58 Zob. Bilans cztonkostwa w UE - Fundusze Europejskie, 30 IV 2013, [online] https://www.funduszeeuropejskie.gov.pl, 27 II 2014.

59 Zob. Ja po prostu mam szczeście. Donald Tusk o wyborach, Polsce na tle Europy, drugorzędności ideologii, siedmiu latach rzadzenia i bilansie osobistym, „Polityka” 2014, 3-9 XII, s. 21. 
Dziś nie ulega wątpliwości, że Polska powinna swoje obecne i przyszłe interesy realizować za pomocą Unii Europejskiej. Dlatego w naszym narodowym interesie leży takie kształtowanie dalszego procesu integracji europejskiej, który będzie czynił Unię bardziej spójną i sprawną oraz umacniał jej pozycję międzynarodową. Unia Europejska powinna wręcz być kamieniem węgielnym obecnej i przyszłej polityki zagranicznej Polski, której nadrzędnym celem nadal jest umacnianie naszej szeroko rozumianej suwerenności. W ramach samej Unii zaś szczególnie powinniśmy pielęgnować stosunki $\mathrm{z}$ sąsiadami, dużymi i małymi. W stosunkach z naszymi mniejszymi sąsiadami powinniśmy kierować się zasadą bezinteresownej życzliwości oraz uwzględniać i wspierać ich potrzeby i postulaty, dzięki czemu zdobędziemy silną pozycję w regionie, co pozwoli nam osiągnąć status mocarstwa regionalnego. Dobrze poprowadzona polska polityka europejska może być olbrzymim wsparciem dla naszego potencjału politycznego i ekonomicznego, jeśli tylko będziemy chcieli twórczo podejść do obecności naszego kraju w procesach wynikających z dynamiki systemu europejskiego i globalnego. Ważnym elementem polskiej strategii integracyjnej powinna być dalsza modernizacja państwa oraz ograniczanie cywilizacyjnych barier oddzielających nasz kraj od głównych państw zachodnioeuropejskich. W celu realizacji polskiej racji stanu władze państwowe winny ułatwiać współpracę paneuropejską, a ograniczać utrudnienia tej współpracy, takie jak: nadmierne ambicje przywódców, bariery historyczne, zagrożenia ekologiczne, stereotypy narodowe czy wzajemna nieufność.

Napawa optymizmem fakt, że powyższe kwestie znalazły szerokie odbicie w podpisanej 5 listopada 2014 r. przez prezydenta Bronisława Komorowskiego nowej Strategii Bezpieczeństwa Narodowego Rzeczypospolitej Polskiej, w której czytamy, że:

Polska jest demokratycznym państwem prawnym z gospodarka rynkowa, przestrzegajacym wiążacego ja prawa międzynarodowego. Polska wzmacnia swój potencjat bezpieczeństwa narodowego, aby zapewnić stabilny rozwój kraju oraz poprawę warunków życia obywateli. Jest aktywnym uczestnikiem wspótpracy międzynarodowej i rozwija przyjazne stosunki oraz wspótprace z państwami bliższego i dalszego sasiedztwa. Cztonkostwo w euroatlantyckich i europejskich strukturach wspótpracy wzmacnia bezpieczeństwo Rzeczypospolitej Polskiej. NATO stanowi najważniejsza forme polityczno-wojskowej wspótpracy Polski z sojusznikami. Unia Europejska wspiera rozwój spoteczno-gospodarczy Polski i umacnia jej pozycję w świecie $e^{60}$.

Można powiedzieć, że jest to efekt trwającej już 26 lat, od upadku w 1989 r. komunizmu w Polsce, transformacji, 17 lat członkostwa Polski w NATO i 12 lat członkostwa w Unii Europejskiej. Jest to efekt przede wszystkim wytężonej pracy milionów Polek i Polaków oraz spełnienia ich marzeń i oczekiwań, aby żyć w wolnej, demokratycznej i suwerennej Polsce oraz w zjednoczonej i bezpiecznej Europie.

Dokonując akcesji do NATO i Unii Europejskiej, Polska powróciła do Europy, która poprzez sukcesywną integrację i zjednoczenie stała się jednym z najważniejszych kontynentów współczesnego świata. Dziś Polska nadal opowiada się za integracją Europy oraz umacnianiem pozycji UE w świecie i jej roli na arenie międzynarodowej w XXI

60 Zob. Strategia Bezpieczeństwa Narodowego Rzeczypospolitej Polskiej, Warszawa 2014, s. 9. 
wieku. Mamy bowiem świadomość, że tylko współpracując z innymi państwami, tak w ramach Unii Europejskiej, jak i NATO, możemy zapewnić sobie pokojowy rozwój, dobrobyt i bezpieczeństwo narodowe. Procesy globalizacji i rosnąca współzależność państw oraz tworzenie się nowego porządku globalnego nie eliminują bowiem różnorakich zagrożeń, a wprost przeciwnie - potęgują je i czynią nieprzewidywalnymi. $\mathrm{Na}$ świecie toczy się obecnie 40 konfliktów zbrojnych, które są źródłem wielkich migracji i mogą stać się zarzewiem nowej wojny światowej ${ }^{61}$.

Niepokój budzą dziś takie zjawiska i procesy, które zagrażają bezpieczeństwu międzynarodowemu, jak: podważanie wiarygodności porozumień rozbrojeniowych, w tym dotyczących nieproliferacji broni masowego rażenia, utrzymywanie się reżimów autorytarnych i postaw konfrontacyjnych, nieposzanowanie zasad prawa międzynarodowego, standardów demokratycznych, praw człowieka, mniejszości etnicznych i religijnych, nasilający się międzynarodowy terroryzm i zorganizowana przestępczość. Wobec tak poważnych zagrożeń Polska musi współpracować z NATO i UE oraz umacniać swoje bezpieczeństwo wespół z innymi państwami należącymi do systemu euroatlantyckiego. Dlatego też w wyżej cytowanej Strategii Bezpieczeństwa RP słusznie podkreślono, że NATO pozostanie najważniejszym sojuszem polityczno-wojskowym oraz gwarantem bezpieczeństwa Polski, a Unia Europejska i rozwijana w jej ramach Wspólna Polityka Bezpieczeństwa i Obrony (WPBiO) będa stanowity istotny czynnik bezpieczeństwa Polski ${ }^{62}$.

Nie ulega więc wątpliwości, że dalszy rozwój WPBiO oraz umacnianie systemu euroatlantyckiego leżą w interesie Polski i są przez Polskę aktywnie wspierane. Ważne jest dążenie do rozwijania w ramach Unii Europejskiej współpracy w zakresie urzeczywistniania Przestrzeni Wolności, Bezpieczeństwa i Sprawiedliwości, w szczególności w obszarze wymiaru sprawiedliwości i spraw wewnętrznych. Polska - jak pokazują minione lata - postrzegała i nadal postrzega integrację z Unią Europejską nie tylko w kategoriach czysto ekonomicznych - konkretnych zysków finansowo-gospodarczych, jakie osiąga dzięki członkostwu, choć niewątpliwie fundusze, które zaczęły płynąć do naszego kraju jeszcze przed 2004 r. i po akcesji do UE, w dużym stopniu wsparły wysiłki modernizacyjne państwa ${ }^{63}$.

Ważniejszy z punktu widzenia strategicznych, długofalowych interesów naszego państwa jest aspekt bezpieczeństwa narodowego, a więc szerszy wymiar zaangażowania Polski w procesy integracyjne w Europie i w umacnianiu pozycji UE na arenie międzynarodowej. Dlatego też Polska po 2004 r. konsekwentnie opowiada się za poszerzaniem i pogłębianiem Unii Europejskiej oraz umacnianiem jej współpracy z NATO i Stanami Zjednoczonymi, które są naszym najważniejszym pozaeuropejskim partnerem. Z perspektywy Warszawy rozszerzenie UE nie jest więc tylko i wyłącznie technicznym oraz politycznym procesem przyjmowania do UE kolejnych (nowych) państw, ale

${ }^{61}$ Tamże, s. 17. Por. także: J.M. Fiszer i in., System euroatlantycki w wielobiegunowym świecie. Próba prognozy, Warszawa 2014, s. 28-29; R. Kuźniar, Europa i porządek międzynarodowy, s. 41-56. 
jest przede wszystkim ważnym instrumentem, dzięki któremu Europa może zachować i umacniać swoją pozycję w świecie.

Polska była, jest i powinna być nadal orędownikiem obiektywnego procesu rozszerzenia, który nie będzie zakładnikiem partykularnych interesów państw członkowskich, gdyż tendencje, które dziś dotyczą głównie rozszerzenia, a więc „nacjonalizacja” tego procesu, bez wątpienia zostaną przeniesione również na inne obszary europejskiej polityki, a nawet już są przenoszone, na przykład odnośnie do polityki migracyjnej. Polska, jako liczące się dziś państwo członkowskie UE, powinna nadal pozycjonować się jako obrońca instytucji wspólnotowych, stojących na straży wypadkowej interesu całej Wspólnoty. Takie są bowiem doświadczenia po 12 latach naszej obecności w Unii Europejskiej. Co więcej, choć dziś perspektywa akcesji dużych państw, np. Turcji i Ukrainy, a także innych państw proradzieckich może wydawać się mało realna czy wręcz nieprawdopodobna, Polska powinna pozostawać orędownikiem członkostwa tych państw w Unii Europejskiej i szerzej, w strukturach euroatlantyckich, tak ze względów geopolitycznych, jak i geoekonomicznych.

Ponadto chciałbym podkreślić, że świat dziś wyraźnie ewoluuje w kierunku multipolarnym i wielocywilizacyjnym, ale rola Europy i w ogóle Zachodu na arenie międzynarodowej maleje. Zachód traci swoje gospodarcze, polityczne, demograficzne i moralne podstawy, a zarazem przestaje być wzorcem rozwojowym dla świata. Tymczasem Unia Europejska, mimo wielu problemów i przeżywanych kryzysów, ma jednak potencjał, aby być i stać się aktywnym podmiotem w systemie euroatlantyckim i w nowym ładzie globalnym. Reprezentuje ponad $507 \mathrm{mln}$ obywateli Europy i ze swym wynoszącym 18,5 bln dolarów PKB stanowi największą gospodarkę na świecie - przed Chinami (17,6 bln) i USA (17,4 bln). Mając 16,2\% udziału w handlu światowym, UE jest potęgą eksportową, daleko przed Chinami (12,7\%) i USA (11,2\%). Także w wydatkach na zbrojenia, które rocznie wynoszą około 322 mld dolarów, co stanowi prawie połowę amerykańskich - 663 mld, Unia jest daleko przed chińskimi - 98 mld. Na 100 najlepszych na świecie uniwersytetów aż 53 są w USA, ale 24 w UE, a w Chinach zaledwie pięć. W liczbie patentów Europa dorównuje Stanom Zjednoczonym, daleko wyprzedzając ChRL ${ }^{64}$.

Jak widać, Unia nie tylko może, ale też powinna być atrakcyjnym partnerem dla Stanów Zjednoczonych, Chin i Indii oraz Rosji i innych mocarstw wschodzących. Musi tylko zacząć prowadzić politykę międzynarodową zgodnie z paradygmatami postulowanymi przez zwolenników teorii realistycznej i przemawiać na forum międzynarodowym jednym głosem, a nie głosami poszczególnych państw członkowskich, które dbają o własne, a nie unijne interesy. Unia Europejska musi się sukcesywnie pogłębiać i poszerzać oraz doskonalić swój system polityczny i gospodarczy (być może w kierunku federalistycznym), aby stać się graczem światowym, tak w aspekcie geoekonomicznym, jak i geopolitycznym.

Natomiast Polska, jako istotny podmiot współczesnych stosunków międzynarodowych, powinna wykorzystać swoje doświadczenia i obecność w Unii Europejskiej do

64 Zob. A. Krzemiński, China dream, „Polityka” 2015, 9-15 IX, s. 56. 
dalszego umocnienia swojej pozycji w Europie i na świecie oraz zintensyfikować dialog i współpracę ze Stanami Zjednoczonymi i państwami należącymi do grupy BRIC.

\section{ZAKOŃCZENIE}

Wydarzenia 1989 r. i akcesja 1 maja 2004 r. do Unii Europejskiej przypominają w naszej historii skok cywilizacyjny Polski piastowskiej sprzed tysiąca lat. Ale dziś, w XXI w., już nie wystarczy być krajem demokratycznym i suwerennym. Musimy jeszcze nauczyć się konkurować, współpracować, a także wspólnie z innymi państwami rozwiązywać problemy pojawiające się w Europie i na świecie, jak np. obecne kryzysy na Ukrainie i w Grecji oraz kryzys spowodowany bezprecedensową imigracją, które zagrażają Polsce i całej Europie. Jednocześnie, aby być aktywnym podmiotem na arenie międzynarodowej, musimy się rozwijać i umacniać, a to oznacza, że Polska musi jak najszybciej osiągnąć poziom rozwoju zbliżony do RFN czy Francji, a więc awansować z obecnej szóstej pozycji w UE na pozycję piątą, a może nawet czwartą. W tym celu nasz PKB per capita wynoszący obecnie 22 tys. dolarów powinien w najbliższych 10 latach się podwoić. Taką szansę daje nam członkostwo w UE, które dzięki zdobytemu doświadczeniu z jednej strony motywuje nas do dokonania nowego skoku cywilizacyjnego, a z drugiej zmusza do aktywności i działań modernizacyjnych - zarówno w sferze politycznej, jak i społeczno-gospodarczej czy naukowej. Tak też myśli większość Polaków, którzy - według różnych sondaży - chcą dalszego pogłębiania i poszerzania Unii oraz opowiadają się za umacnianiem jej roli na arenie międzynarodowej. Od wielu lat wśród Polaków istnieje też najwyższy odsetek euroentuzjastów, sięgający $80 \%$ badanych respondentów ${ }^{65}$.

Ponadto większość Polaków jest dziś przekonana, że przyjęcie Polski do NATO w dniu 12 marca 1999 r. oraz do Unii Europejskiej 1 maja 2004 r. to nasze największe sukcesy w polityce światowej na przełomie XX i XXI w., które nie tylko nobilitują Polskę, ale także wzmacniają jej suwerenność i bezpieczeństwo narodowe ${ }^{66}$. Po 12 latach członkostwa Unia nam spowszedniała, stała się częścią codziennego życia Polaków, żeby wymienić chociażby takie kategorie, jak: studia, praca, biznesy, emigracja, turystyka, dotacje, inwestycje, popkultura itp. Już nie ma śladu po emocjach, jakie towarzyszyły Polakom, gdy 1 maja 2004 r. na pl. Piłsudskiego w Warszawie po raz pierwszy wciągano na maszt, obok polskiej, unijną flagę, co odczytywano wówczas jako symbol końca naszej historii. Tej, która zaczęła się pół wieku wcześniej w Jałcie na Krymie i w Poczdamie, a na którą nie mieliśmy większego wpływu.

65 W lutym 2013 r. 78\% Polaków popierało integrację europejską, ale zaledwie 29\% opowiadało się za przystąpieniem do strefy euro. Obawy i nadzieje zwiazane $z$ wprowadzeniem euro w Polsce, Komunikat z badań BS/42/2013, Warszawa, marzec 2013, [online] http://www.cbos.pl/SPISKOM.POL/2013/K_042_13.PDF, 22 V 2014.

66 Zob. J.M. Fiszer, Suwerenność Polski po dziesięciu latach cztonkostwa w Unii Europejskiej, [w:] Polska w procesie integracji europejskiej..., s. 29-59; Z. Czachór, Polska w Unii Europejskiej. Między uniwersalizmem a partykularyzmem, [w:] Polska w procesie integracji europejskiej..., s. 13-28. 
Ogólnie rzecz biorąc, członkostwo w Unii Europejskiej obok pewnych wad dało nam szansę dalszego rozwoju, ale wymaga to nowej, przemyślanej strategii i wzmożonej aktywności po stronie polskich elit i całego narodu. Nie zwalnia nikogo z odpowiedzialności za losy kraju ani nie powinno prowadzić do przekazania całości władzy do instytucji europejskich. $Z$ drugiej strony integracja narzuca Polsce określone reguly gry. Stanowią one ramy dla polskiego rozwoju, ujmowanego w szerokim sensie, a więc nie tylko w aspekcie ekonomicznym i społecznym, ale także na płaszczyźnie geopolitycznej. Polska ostatecznie bowiem zmieniła kontekst sojuszy międzynarodowych jednak zasadniczo nie wyzwoliła się ze statusu peryferyjnego. A to oznacza, że wciąż ma stosunkowo niewielki wpływ na kluczowe decyzje podejmowane w ramach europejskiego systemu władzy. Istnieje tutaj pewne napięcie między szansami, jakie stwarza integracja europejska, a ograniczeniami, jakie ona narzuca. Polska uzyskała historyczną okazję poprawy pozycji międzynarodowej, czyli możliwość awansu z peryferii do tzw. półperyferii europejskich. Ale jest to tylko szansa, która może być zmarnowana, a europeizacja może nawet utrwalić naszą zależność i peryferyjność na mapie geopolitycznej $j^{67}$.

Członkostwo Polski w Unii Europejskiej nie powinno więc usypiać czujności polskich elit i prowadzić do przerzucania odpowiedzialności geostrategicznej na instytucje europejskie bądź na największe państwa Unii Europejskiej, czyli na niemiecko-francuski tandem, który powoli rozpada się i zawodzi, jak pokazuje to rosyjska aneksja Krymu oraz kryzysy na Ukrainie i w Grecji. Polska powinna rewitalizować Trójkąt Weimarski oraz Trójkąt Wyszehradzki i w oparciu o te struktury oraz we współpracy z krajami basenu Morza Bałtyckiego budować silną pozycję w Unii Europejskiej i na świecie.

Podsumowując nasze dotychczasowe członkostwo w Unii Europejskiej, chciałbym przytoczyć opinię na ten temat wyrażoną przez przewodniczącego Parlamentu Europejskiego Martina Schulza, który pisze, że:

$W$ ciagu dziesięciu lat swojego cztonkostwa w Unii Europejskiej Polska przeszta imponujący rozwój. [...] Polskie stanowisko liczy się w Unii Europejskiej, co więcej Polska wyznacza ważne akcenty $w$ dalszym ksztaltowaniu i integracji wspólnoty. Polscy europarlamentarzyści wnosza cenny wktad w prace parlamentu, nigdy nie tracac z oczu wspólnego interesu europejskiego. Polska odnalazta swoja role w Unii Europejskiej. Jest to zmiana, która szczególnie cieszy mnie - niemieckiego przewodniczącego międzynarodowego parlamentu $^{68}$.

Ważnym wydarzeniem było sprawowanie przez Polskę w drugiej połowie $2011 \mathrm{r}$. pierwszej po akcesji prezydencji w Radzie UE. Nie ulega wątpliwości, że było to wydarzenie, dzięki któremu Polska ostatecznie potwierdziła swój powrót do Europy. Polska, sprawując prezydencję przez pół roku, znajdowała się w ścisłym centrum decyzyjnym UE, de facto była jej gospodarzem. Nasze przewodnictwo zostało bardzo dobrze ocenione przez państwa członkowskie i instytucje unijne. Podkreślano profesjonalizm polskich urzędników i skuteczność negocjatorów. Martin Schulz, ówczesny lider socjal-

67 Szerzej na ten temat zob. T.G. Grosse, W objęciach europeizacji, Warszawa 2012. 
demokratów w Parlamencie Europejskim, stwierdzil, że byta to najlepsza prezydencja ostatnich lat, a ówczesna szefowa unijnej dyplomacji Catherine Ashton mówiła o bardzo dobrym przewodnictwie ${ }^{69}$. Błędem zaś - moim zdaniem - było nadmierne angażowanie się w tzw. politykę wschodnią UE, co doprowadziło do zaognienia naszych stosunków z Rosją.

Polska dzięki akcesji do UE zyskała większe zaufanie, także sąsiadów, i zaczęto ją postrzegać jako kraj demokratyczny, stabilny i przewidywalny. Stała się dzięki temu poważnym, aktywnym uczestnikiem stosunków międzynarodowych i dziś może skuteczniej wpływać na losy Europy i całego świata. Dążyliśmy za wszelką cenę do tego, aby w NATO i Unii Europejskiej znaleźli się też nasi sąsiedzi. Wysiłki te zostały uwieńczone sukcesem. Czesi, Słowacy, Litwini - bezpośredni sąsiedzi, z którymi w przeszłości nie zawsze potrafiliśmy współpracować - dziś są naszymi sojusznikami i partnerami. Nadal też popieramy dążenia Białorusinów i Ukraińców do członkostwa w UE oraz powinniśmy szukać porozumienia z Rosją, a unikać zadrażnień i konfrontacji. Musimy je osiągnąć, bo jest to niezbędne dla dobra Polski i Rosji oraz dla UE i całej Europy. Dla Rosji stosunki z Polską to więcej niż po prostu stosunki z zachodnim krajem. Rozmawiać z Zachodem, kontaktując się tylko z Niemcami i Francją, to dziś za mało. Polska powinna domagać się od Rosji tego, czego Rosja chce od Stanów Zjednoczonych, mianowicie, żeby traktować ją poważnie, żeby jej interesy były w Moskwie brane pod uwagę nawet przy istniejących różnicach, których szybko nie da się zniwelować ${ }^{70}$.

Co więcej, jak już wspominałem, polska polityka zagraniczna powinna konsekwentnie zmierzać do osiągnięcia przez Polskę pozycji przywódczej w Europie Środkowej i Wschodniej oraz do zdobycia znaczącej roli w strukturach euroatlantyckich. Polska w roli przywódcy regionalnego nie jest bowiem tylko mrzonką, wywołaną wybujałymi ambicjami polityków. Status taki jest realny dla Polski. Co więcej, umocniłby on naszą suwerenność zewnętrzną i tożsamość narodową, które w warunkach postępującej globalizacji i integracji są narażone na pewne zagrożenia ${ }^{71}$.

Jest to możliwe, ale pod warunkiem, że położony zostanie nacisk na rozwój polskiego przemysłu i rolnictwa, nauki i techniki. Musimy zapewnić godziwe warunki do egzystencji i rozwoju całego społeczeństwa, a zwłaszcza ludzi młodych, aby będąc w UE, pozostali jednak w Polsce.

69 Zob. J. M. Fiszer, Pozytywne i negatywne przestanki polskiej prezydencji w Radzie Unii Europejskiej oraz jej bilans, [w:] Prezydencja Polski w Radzie Unii Europejskiej, red. tenże, Warszawa 2012, s. 42; B. Nowak, Ostatnia prezydencja dużch oczekiwań - refleksje po prezydencji Polski w Radzie UE, Warszawa 2012, s. 3-18, Raporty i Analizy, nr 2.

70 Zob. T. Borisowa, Jak gdyby nigdy nic?, „Biełaruś Siegodnia” 2010, 26 X, [za:] „Forum” 2010, nr 44/45, s. 6-7.

${ }_{71}$ Zob. J.M. Fiszer, Suwerenność Polski i tożsamość narodowa w świetle Konstytucji RP i Konstytucji Europejskiej, „Politeja” 2005, nr 2, s. 45-46; K. Szczerski, Dynamika systemu europejskiego. Rozważania o nowym ksztatcie polityki Unii Europejskiej, Kraków 2008, s. 182-183. 


\section{BIBLIOGRAFIA}

\section{Źródła}

Informacja Ministra Spraw Zagranicznych o zadaniach polskiejpolityki zagranicznej w 2013 roku, 20 III 2013, [online] http://www.msz.gov.pl.

Informacja Ministra Spraw Zagranicznych o zadaniach polskiejpolityki zagranicznej w 2014 roku, 8 V 2014, [online] http://www.msz.gov.pl.

Komunikat CBOS - Polacy oceniaja 10 lat w Unii Europejskiej, [online] http://wiadomości. dziennik.pl/wybory/artykuły/457183. cbos-polacy-oceniają-10-lat-w-unii.html.

Obawy i nadzieje zwiazane $z$ wprowadzeniem euro $w$ Polsce, Komunikat z badań BS/42/2013, Warszawa, marzec 2013, [online] http://www.cbos.pl/SPISKOM.POL/2013/K_042_ 13.PDF.

Rada Europejska 19-20 grudnia 2013 r. Konkluzje, [online] http://www.consilium.europa.eu. Sejm RP, Kadencja VII, Sprawozdanie stenograficzne z 3 posiedzenia Sejmu RP, 15 XII 2011 (drugi dzień obrad), Warszawa 2011, [online] http://orka2.sejm.gov.pl/StenoInter7.nsf/0/ BC8CC 970 .

Strategia Bezpieczeństwa Narodowego Rzeczypospolitej Polskiej, Biuro Bezpieczeństwa Narodowego, Warszawa 2014.

\section{Literatura}

Baczyński J., Czy porwiemy Europę?, „Polityka” 2011, 6-12 VII.

Barburska O., Relacje Unia Europejska-Federacja Rosyjska. Kryzys partnerstwa strategicznego, „Studia Europejskie” 2014, nr 4.

Barburska O., Wptyw polskiej dyplomacji na ksztattowanie i realizacje polityki wschodniej UE, „Studia Europejskie” 2013, nr 4.

Barroso J. M., Europa doszta do ściany, „Gazeta Wyborcza” 2012, 13 IX.

Beck U., Grande E., Europa kosmopolityczna. Spoteczeństwo i polityka w drugiej nowoczesności, przeł. A. Ochocki, Warszawa 2009.

Bendyk E., Odzyskiwanie demokracji, „Res Publica Nowa” 2014, 26 V.

Bem K., Makowski J., Biedni Polacy patrza na uchodźców, „Gazeta Wyborcza” 2015, 10 IX.

Betz H. G., Warunki sukcesu (klęski) populistycznych partii radykalnej prawicy we wspótczesnych systemach demokratycznych, [w:] Demokracja w obliczu populizmu, red. Y. Mény, Y. Surel, przet. A. Gąsior-Niemiec, Warszawa 2007.

Bielecka M., Role międzynarodowe państwa, [w:] Wstęp do teorii polityki zagranicznej, red. R. Zięba, Toruń 2007.

Bielecki T., Zamiast Grexitu cięcia i nowe kredyty, „Gazeta Wyborcza” 2015, 14 VII.

Bielecki P., Kto zmięknie pierwszy - Unia Europejska czy Putin?, „Gazeta Wyborcza” 2015, 7 I.

Bieleń S., Stosunki Unia Europejska-Rosja, [w:] Dyplomacja czy sita? Unia Europejska w stosunkach międzynarodowych, red. S. Parzymies, Warszawa 2009.

Bilans cztonkostwa w UE - Fundusze Europejskie, 30 IV 2013, [online] https://www.funduszeeuropejskie.gov.pl.

Bilans pierwszych lat cztonkostwa Polski w Unii Europejskiej, red. J.M. Fiszer, Warszawa 2011. 
Bogdandy A., Demokratie, Globalisirung. Zukunft des Völkerrechts - eine Bestandsaufnahme, „Zeitschrift für ausländisches öffentliches Recht und Völkerrecht” 2003, nr 1.

Borisowa T., Jak gdyby nigdy nic?, „Biełaruś Siegodnia” 2010, 26 X, [za:] „Forum” 2010, nr 44/45.

Borkowski P.J., Międzyrządowość w procesie integracji europejskiej, Warszawa 2013.

Borkowski P.J., Nie takie państwo straszne jak je maluja - o funkcjach czynnika międzyrządowego w procesie integracji europejskiej, [w:] Polityczne wyzwania wspótczesnych państw, t. 1: Perspektywa globalna, red. W. Gizicki, Torun 2012.

Brzeziecki A., Tadeusz Mazowiecki. Biografia naszego premiera, Kraków 2015.

Cianciara A.K., Zróżnicowana integracja w Unii Europejskiej i scenariusze ewolucji stosunków transatlantyckich, [w:] Wspótpraca transatlantycka. Aspekty polityczne, ekonomiczne, spoteczne, red. J.M. Fiszer i in., Warszawa 2014.

Cianciara A.K., Wielobiegunowa Europa w wielobiegunowym świecie. Szansa czy wyzwanie dla systemu euroatlantyckiego?, Warszawa 2012.

Ciechański J., Problem modernizacji Unii Europejskiej w świetle strategii Europa 2020. Problem zmiany paradygmatu integracyjnego, [w:] Strategia rozwoju Unii Europejskiej, red. J. Adamowski, K.A. Wojtaszczyk, Warszawa 2010.

Cimoszewicz W., Krajobraz za horyzontem. Polityka zagraniczna RP po wejściu do Unii Europejskiej, „Sprawy Międzynarodowe” 2004, nr 2.

Ciupiński A., Zaangażowanie Polski w realizację Wspólnej Polityki Bezpieczeństwa i Obrony Unii Europejskiej. Bilans pierwszej dekady cztonkostwa w UE, [w:] Dziesięć lat cztonkostwa Polski w Unii Europejskiej. Próba bilansu i nowe otwarcie, red. J.M. Fiszer, Warszawa 2015.

Czachór Z., Polska w Unii Europejskiej. Między uniwersalizmem a partykularyzmem, [w:] Polska w procesie integracji europejskiej. Dekada doświadczeń (2004-2014), red. K.A. Wojtaszczyk, M. Mizerska-Wrotkowska, W. Jakubowski, Warszawa 2014.

Czaputowicz J., Suwerenność, Warszawa 2013.

Czarnecki M., Rębała M., Europejczycy zawieszeni między strachem a wspótczuciem, „Gazeta Wyborcza” 2015, 10 IX.

Czerny I., Korpus na wielbtądzie, „Polityka” 2010, 30 X.

Demokratyzacja i wzmocnienie legitymacji Unii Europejskiej, red. J. Barcz, Warszawa 2005.

Duszczyk M., Od Strategii Lizbońskiej do Europa 2020 - lekcja dla Unii Europejskiej, [w:] Strategia rozwoju Unii Europejskiej, red. J. Adamowski, K.A. Wojtaszczyk, Warszawa 2010.

Dziamski G., Rola kultury w procesie integracji europejskiej, „Europa Wschodu i Zachodu” 1999, nr 3.

Dziesięć lat polskich doświadczeń w Unii Europejskiej. Problemy prawnoadministracyjne, red. J. Sługocki, Wrocław 2014.

Efektywność reprezentacji interesów Polski w Unii Europejskiej, red. K.A. Wojtaszczyk, Warszawa 2011.

Eijk C. van der, Franklin M., Potential for Contestation on European Matters at National Elections in Europe, [w:] European Integration and Political Conflict, red. G. Marks, M.R. Steenbergen, Cambridge 2004.

Erler G., Mit einer neuen Ostpolitik aus der Krise?, „Neue Gesellschaft-Frankfurter Hefte” 2015, nr $7 / 8$. 
Europejska Polityka Sąsiedztwa. Geneza, doświadczenia, perspektywy, red. J.M. Fiszer, Warszawa 2012.

Fiszer J.M., Czy państwo demokratyczne może być wzorem dla przysztej Unii Europejskiej?, „Myśl Ekonomiczna i Polityczna” 2014, nr 1(44).

Fiszer J.M., Korzyści i zagrożenia oraz koszty przystąpienia Polski do Unii Europejskiej, „Przegląd Europejski” 2001, nr 1.

Fiszer J.M., Modernizacja Unii Europejskiej - istota, przestanki i perspektywy, [w:] Modernizacja procesów integracji europejskiej, red. K. A. Wojtaszczyk, Warszawa 2011.

Fiszer J.M., Pozytywne i negatywne doświadczenia Polski po dziesięciu latach członkostwa w Unii Europejskiej. Próba bilansu i nowe otwarcie, Warszawa 2015.

Fiszer J.M., Pozytywne i negatywne przestanki polskiejprezydencji w Radzie Unii Europejskiej oraz jej bilans, [w:] Prezydencja Polski w Radzie Unii Europejskiej, red. tenże, Warszawa 2012.

Fiszer J.M., Suwerenność Polski i tożsamość narodowa w świetle Konstytucji RP i Konstytucji Europejskiej, „Politeja” 2005, nr 2.

Fiszer J.M., Suwerenność Polski po dziesięciu latach cztonkostwa w Unii Europejskiej, [w:] Polska $w$ procesie integracji europejskiej. Dekada doświadczeń (2004-2014), red. K.A. Wojtaszczyk, M. Mizerska-Wrotkowska, W. Jakubowski, Warszawa 2014.

Fiszer J.M., System euroatlantycki przed i po zakończeniu zimnej wojny. Istota, cele i zadania oraz rola w budowie nowego tadu globalnego, Warszawa 2013.

Fiszer J.M., Szanse i zagrożenia dla modernizacji Unii Europejskiej w dobie kryzysu i ksztattowania się nowego tadu globalnego, [w:] Zarządzanie procesem integracji i modernizacja Unii Europejskiej, red. tenże, M.J. Tomaszyk, Warszawa 2013.

Fiszer J.M., Unia Europejska a Polska - dziś i jutro, Toruń 2002.

Fiszer J.M., Unia Europejska jedenaście lat od rozszerzenia na Wschód i jejperspektywy w XXI wieku, „Myśl Ekonomiczna i Polityczna” 2015, nr 1(48).

Fiszer J.M., Wspólnota euroatlantycka i jejperspektywy w nowym systemie międzynarodowym, cz. 2, „Studia Polityczne” 2015, nr 2.

Fiszer J.M. i in., System euroatlantycki w wielobiegunowym świecie. Próba prognozy, Warszawa 2014.

Fücks R., Koniec z wygodnictwem, Warszawa, 11 VII 2014, [online] http://boell.org/pl/2014/ 07//02/koniec-z-wygodnictwem.

Gańczyk F., Trudna gościnność, „Polityka” 2015, 9-15 IX.

Graczyk R., Od uwiktania do autentyczności. Biografia polityczna Tadeusza Mazowieckiego, Warszawa 2015.

Gravier M., Empire vs. Federation. Which Path for Europe?, „Journal of Political Power” 2011, nr 7.

Greiner J., Rechtspopulismus als sozialdemokratische Herausforderung - Das Beispiel Skandinavien, „Neue Gesellschaft-Frankfurter Hefte” 2015, nr 7/8.

Grochalski M., Wykorzystanie form demokracji bezpośredniej w procesach integracyjnych Unii Europejskiej, [w:] Wybrane zagadnienia polskiej i europejskiej demokracji, red. S. Wróbel, Toruń 2008.

Grosse T.G., Wobjęciach europeizacji, Warszawa 2012.

Grosse T.G., Woczekiwaniu na rewolucje, „Rzeczpospolita” 2014, 22 VII. 
Grzeszczak R., Legitymizacja demokratyczna Unii Europejskiej (ewolucja procesu legislacyjnego i rola parlamentów narodowych), [w:] Suwerenność i ponadnarodowość a integracja europejska, red. J. Kranz, Warszawa 2006.

Habermas J., The Crisis of the European Union in the Light of a Constitutionalization of International Law, „European Journal of International Law” 2012, nr 2.

Hypki T., Nowy wyścig zbrojeń w Europie?, „RAPORT. Wojsko. Technika. Obronność” 2015, nr 9.

Janicki M., Ucieczka na Zachód, „Polityka” 2014, 26 III-1 IV.

Ja po prostu mam szczęście. Donald Tusk o wyborach, Polsce na tle Europy, drugorzędności ideologii, siedmiu latach rządzenia i bilansie osobistym, „Polityka” 2014, 3-9 XII.

Jaskiernia J., Pozycja Parlamentu Europejskiego w systemie instytucjonalnym Unii Europejskiej po Traktacie z Lizbony, [w:] Parlament Europejski po Traktacie z Lizbony. Doświadczenia i nowe wyzwania, red. J.M. Fiszer, Warszawa 2011.

Jaskiernia J., Traktat z Lizbony a problem legitymizacji demokratycznej Unii Europejskiej, [w:] Prawowitość czy zgodność z prawem. Legitymacja wtadzy w państwach demokratycznych, red. A. Preisner, Wrocław 2010.

Juncker J.C., Raport o stanie Unii Europejskiej. Pora na uczciwość, jednosśc i solidarność, „Gazeta Wyborcza” 2015, 12-13 IX.

Kabat-Rudnicka D., Zasada federalna a integracja ponadnarodowa. Unia Europejska między federalizmem dualistycznym a kooperatywnym, Kraków 2010.

Kopka A., Populizm lewicowy w Europie na przyktadzie partii „Die Linke” w Republice Federalnej Niemiec, „Przegląd Politologiczny” 2010, nr 4.

Koziej S., Potrzeba nowelizacji strategii bezpieczeństwa Unii Europejskiej, „Bezpieczeństwo Narodowe" 2011, nr 4(20).

Kranz J., Wyrozumska A., Powierzenie Unii Europejskiej niektórych kompetencji a Traktat fiskalny, „Państwo i Prawo” 2012, nr 7.

Kranz J., Deficyt demokracji w Unii Europejskiej?, „Sprawy Międzynarodowe” 2012, nr 3.

Kranz J., Jak rozumieć suwerenność? Próba opisu, [w:] Suwerenność państwa i jej granice, red. S. Sowiński, J. Węgrzecki, Warszawa 2010.

Krasowski R., Imperium świętego spokoju, „Polityka” 2014, 7-13 V.

Krastew I., Najpierw farsa, potem rozpacz, „Gazeta Wyborcza” 2015, 18-19 VII.

Krzemiński A., Car jest nagi, „Polityka” 2014, 10-16 XII.

Krzemiński A., China dream, „Polityka” 2015, 9-15 IX.

Krzemiński A., Gule i bóle, „Polityka” 2014, 16-22 VII.

Krzemiński A., Martin Schulz i jego pomysty na Europe, „Polityka” 2013-2014, 27 XII-7 I.

Krzemiński A., Niemcy na huśtawce, „Polityka” 2014, 30 VII-5 VIII.

Kułakowski J., Jesień L., Przebieg negocjacji akcesyjnych Polski w 2001 roku, „Rocznik Polskiej Polityki Zagranicznej" (Warszawa) 2002.

Kupiecki R., Unia Europejska i problemy strategii bezpieczeństwa podmiotów zbiorowych, „Sprawy Międzynarodowe” 2014, nr 4.

Kuźniar R., Droga do wolności. Polityka zagraniczna III Rzeczypospolitej, Warszawa 2008.

Kuźniar R., Europa i porządek międzynarodowy, „Stosunki Międzynarodowe - International Relations" 2014, t. 50, nr 2. 
Lewandowski J., Unia Europejska - to ostatni dzwonek..., „Puls Biznesu” 2013, 31 I.

Leuffen D., Rittberger B., Schimmelfennig F., Differential Integration. Explaining Variation in the European Union, Basingstoke 2013.

Lutkowski L., Rozpad strefy euro - ponura wizja czy realna możliwość?, [w:] Kryzys finansów publicznych. Przyczyny, mechanizmy, drogi wyjścia, red. L. Oręziak, D.K. Rosati, Warszawa 2013.

Łastawski K., Polska racja stanu po wstąieniu do Unii Europejskiej, Warszawa 2009.

Łoś-Nowak T., Polska - cele, aspiracje, kierunki, [w:] Polityka zagraniczna. Aktorzy, potencjaty, strategie, red. taż, Warszawa 2011.

Madej M., Wptyw udziatu w Wspólnej Polityce Bezpieczeństwa i Obrony na polską politykę bezpieczeństwa, [w:] Polska w Unii Europejskiej. Bilans dekady, red. F. Tereszkiewicz, Warszawa 2013.

Majewski P., Europy nie zdziwia nasi eurosceptycy, „Rzeczpospolita” 2014, 30 V.

Malendowski W., Suwerenność państw w procesie integracji europejskiej, „Przegląd Politologiczny" 2010, nr 4.

Maziarski W., PiS straszy Niemcami - że szantażują Europe uchodźcami, „Gazeta Wyborcza” 2015, 10 IX.

Michałowska G., Polska w międzynarodowych stosunkach kulturalnych, [w:] Polska w stosunkach międzynarodowych, red. S. Bieleń, Warszawa 2007.

Miszczak K., The Polish Security and Defence Policy, „European Security \& Defence” 2015, nr 5.

Miszczak K., Wspólna Polityka Zagraniczna i Bezpieczeństwa, „Sprawy Międzynarodowe” 2007, $\mathrm{nr} 4$.

Mniej Europy, więcej Europy. Z Iwanem Krastewem rozmawia Adam Leszczyński, „Gazeta Wyborcza" 2014, 31 V-1 VI.

Moroska A., Prawicowy populizm a eurosceptycyzm (na przyktadzie Listy Pima Fortuyna w Holandii i Ligi Polskich Rodzin w Polsce), Wrocław 2010.

Multi-Level Governance w Unii Europejskiej, red. J. Ruszkowski, L. Wojnowicz, Szczecin-Warszawa 2013.

Nowak A., Putin. Źródta imperialnej agresji, Warszawa 2014.

Nowak B., Ostatnia prezydencja dużych oczekiwań - refleksje po prezydencji Polski w Radzie UE, Warszawa 2012, Raporty i Analizy, nr 2.

Orzelska-Stączek A., Rola Polski w euroatlantyckim systemie bezpieczeństwa w ocenie gtównych sit politycznych, [w:] System euroatlantycki i bezpieczeństwo międzynarodowe $w$ multipolarnym świecie. Miejsce i rola Polski w euroatlantyckim systemie bezpieczeństwa, red. J.M. Fiszer, Warszawa 2013.

Osiem lat gospodarki pod rządami Platformy i ludowców, „Gazeta Wyborcza” 2015, 5-6 IX.

Ostrowski M., Koniec marzeń, „Polityka” 2014, 4-10 VI.

Parlament Europejski po Traktacie z Lizbony. Doświadczenia i nowe wyzwania, red. J.M. Fiszer, Warszawa 2011.

Piskorska B., Adaptacja Unii Europejskiej i Polski do nowych uwarunkowań bezpieczeństwa w Europie Wschodniej. Kazus Ukrainy, [w:] Dziesięć lat cztonkostwa Polski w Unii Europejskiej. Próba bilansu i nowe otwarcie, red. J.M. Fiszer, Warszawa 2015.

Polska w Unii Europejskiej. Bilans dekady, red. F. Tereszkiewicz, Warszawa 2013. 
Polska w procesie integracji europejskiej. Dekada doświadczeń (2004-2014), red. K.A. Wojtaszczyk, M. Mizerska-Wrotkowska, W. Jakubowski, Warszawa 2014.

Polska w stosunkach międzynarodowych, red. S. Bieleń, Warszawa 2007.

Polskie 10 lat w Unii. Raport, red. Kałużyńska M. i in., Warszawa 2014.

Przemówienie Jana Pawta II w Parlamencie RP w dniu 11 czerwca 1999 roku, „Rzeczpospolita” 1999, 12 VI.

Rolnicy wyszli na swoje, [w:] 10 lat w Unii, dodatek specjalny „Polityki” 2014, 28 IV-5 V.

Rosati D.K., Czy strefa euro przetrwa kryzys?, [w:] Kryzys finansów publicznych. Przyczyny, mechanizmy, drogi wyjścia, red. L. Oręziak, D.K. Rosati, Warszawa 2013.

Rotfeld A.D., Porządek międzynarodowy. Parametry zmiany, „Sprawy Międzynarodowe” 2014, nr 4.

Roubini N., Mihm S., Ekonomia kryzysu, przeł. R. Mitoraj, Warszawa 2011.

Schimmelfennig F., EU Enlargement and Differentiation. Discrimination or Equal Treatment?, "Journal of European Public Policy" 2014, Vol. 21, nr 5.

Schimmelfenning F., The Normative Origins of Democracy in the European Union. Towards a Transformationist Theory of Democratization, „European Political Science Review” 2010, nr 2.

Schulz M., Skrępowany olbrzym. Ostatnia szansa Europy, Warszawa 2014.

Sługocki W., Polityka regionalna Unii Europejskiej a rozwójpolskich regionów - studium przypadku, Zielona Góra 2013.

Słowikowski M., Rosja wobec Europejskiej Polityki Sasiedztwa Unii Europejskiej, „Rocznik Instytutu Europy Środkowo-Wschodniej” (Lublin) 2008.

Smoczyński W., Europa się chwieje, „Polityka” 2011, 29 VI-5 VII.

Suwerenność i ponadnarodowość a integracja europejska, red. J. Kranz, Warszawa 2006.

System euroatlantycki i bezpieczeństwo międzynarodowe w multipolarnym świecie. Miejsce i rola Polski w euroatlantyckim systemie bezpieczeństwa, red. J.M. Fiszer, Warszawa 2013.

Szczerski K., Dynamika systemu europejskiego. Rozważania o nowym ksztatcie polityki Unii Europejskiej, Kraków 2008.

Szymczyński T.R., Horyzonty sporu wokót zjawiska deficytu demokratycznego w Unii Europejskiej, Warszawa 2013.

Tatham A.F., Enlargement of the European Union, London 2009.

Unia Europejska jako aktor na scenie globalnej. Razem czy osobno?, red. B. Góralczyk, Warszawa 2014.

Unia Europejska jako wspótczesny aktor stosunków międzynarodowych, red. J. Knopek, Toruń 2009.

Wedel-Domaradzka A., Parlament Europejski a prawa cztowieka - uwagi na tle postępujacej integracji, demokratyzacji i norm prawa międzynarodowego, [w:] Parlament Europejski po Traktacie z Lizbony. Doświadczenia i nowe wyzwania, red. J.M. Fiszer, Warszawa 2011.

Wessels W., An Ever Closer Fusion? A Dynamic Macropolitical View on Integration Process, „Journal of Common Market Studies" 1997, nr 2.

Węc J.J., Spór o ksztatt ustrojowy Wspólnot Europejskich i Unii Europejskiej w latach 1955-2010. Między idea ponadnarodowości a wspótpraca międzyrządowa. Analiza politologiczna, Kraków 2012.

Wielowiejski A., Tadeusz Skuteczny, „Gazeta Wyborcza” 2015, 12-13 IX. 
Willa R., Deficyt demokratyczny w Unii Europejskiej, „Athenaeum - Polski Przegląd Politologiczny" 2010, t. 23.

Wojciechowski M., Suwerenność tkwi w portfelu, „Gazeta Wyborcza” 2011, 21 XII.

Wódka J., Polityka zagraniczna „nowej” Turcji. Implikacje dla partnerstwa transatlantyckiego, Warszawa 2013.

Wójcik Ł, Strefa bólu, „Polityka” 2015, 1-7 VII.

Wójcik Ł., Więzień Kremla, „Polityka” 2015, 1-6 I.

Wptyw cztonkostwa Polski w Unii Europejskiej i realizowanej polityki spójności na rozwój kraju, Warszawa 2014.

Zając J., Role międzynarodowe państwa średniego, „Krakowskie Studia Międzynarodowe” 2013, nr 4.

Zielonka J., Europa jako imperium. Nowe spojrzenie na Unię Europejska, Warszawa 2006.

Zięba R., Międzynarodowe implikacje kryzysu ukrainskiego, „Stosunki Międzynarodowe - International Relations" 2014, t. 50, nr 2.

Prof. dr hab. Józef M. FISZER - profesor zwyczajny, historyk, politolog, niemcoznawca, kierownik Zakładu Europeistyki Instytutu Studiów Politycznych PAN (ISP PAN), sekretarz, wiceprzewodniczący Rady Naukowej ISP PAN, członek Komitetu Nauk Politycznych PAN od 1993 r., sekretarz naukowy KNP PAN (1993-2009), wiceprzewodniczący KNP PAN (2001-2012); członek Komitetu Narodowego ds. Współpracy z Międzynarodowym Stowarzyszeniem Nauk Politycznych (IPSA) - The Polish National Committee for Cooperation with the International Political Science Association (2001-2012); członek zespołu ekspertów Euro-them, powołanego przez Komisję Europejską (od 2010 r.); kierownik Katedry Międzynarodowych Stosunków Politycznych Uczelni Łazarskiego w Warszawie. Autor i redaktor naukowy ponad 350 prac naukowych z zakresu historii i współczesnych stosunków międzynarodowych oraz poświęconych polityce zagranicznej Polski, stosunkom polsko-niemieckim i Unii Europejskiej. Redaktor naczelny „Myśli Ekonomicznej i Politycznej” - kwartalnika naukowego wydawanego przez Uczelnię Łazarskiego w Warszawie. Członek wielu rad redakcyjnych i naukowych w kraju i za granicą. 